\title{
Synthesis and conformational analysis of novel naphthoxazine-fused polyheterocycles
}

Ph.D. Thesis

Petra Barta

\author{
Supervisors: \\ Dr. István Szatmári \\ Prof. Dr. Ferenc Fülöp
}

Institute of Pharmaceutical Chemistry

University of Szeged 
"Success is a science; if you have the conditions, you get the result."

Oscar Wilde 


\section{CONTENTS}

CONTENTS .3

PUBLICATIONS .5

1. INTRODUCTION AND AIMS 7

2. LITERATURE BACKGROUND .9

2.1. ortho-Quinone methide mediated, Mannich base connected syntheses .....................................9

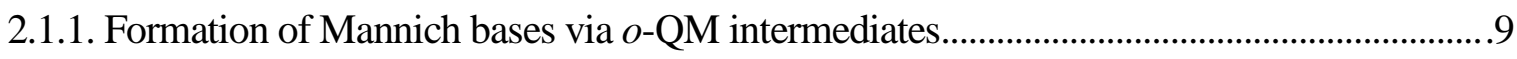

2.1.1.1. Amidoalkylnaphthols ...............................................................................................

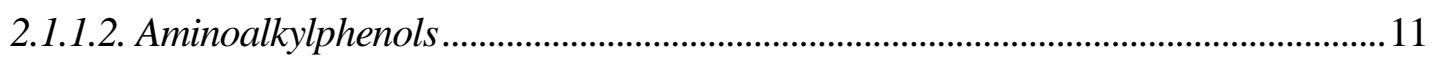

2.1.2. Reactions of $o$-QMs formed by Mannich bases ....................................................................... 13

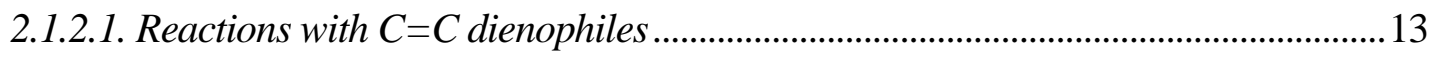

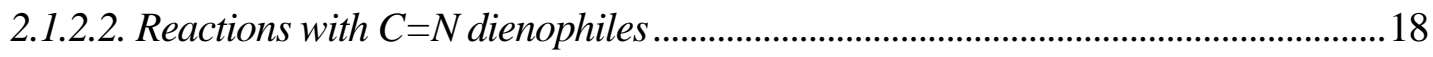

2.1.2.3. Reactions with electron-rich aromatic compounds ................................................19

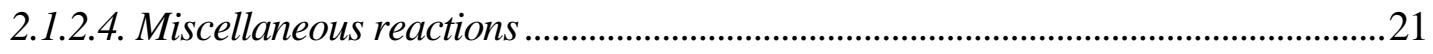

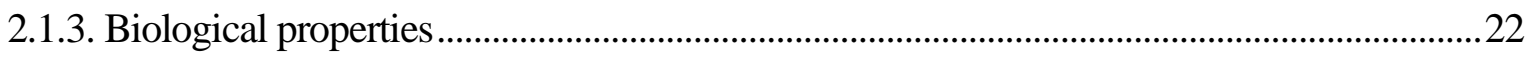

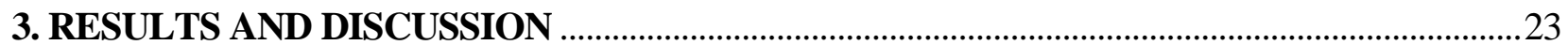

3.1. Synthesis of new naphthoxazines, oxazinoisoquinolines and oxazinoquinolines via C1 coupling of cyclic imines with electron-rich aromatic compounds

3.1.1. C1 coupling of 4,5-dihydro-3H-benz[c]azepine with 1- and 2-naphthol or their $N$ containing analogues

3.1.2. C1 coupling of 6,7-dihydrothieno[2,3-c]pyridine with 1- and 2-naphthol or their $N$ containing analogues

3.1.3. C1 coupling of (4aS,8aS)-4a,5,6,7,8,8a-hexahydro-2-quinoxalinone with 1- and 2-naphthol.

3.1.4. Ring-closure reactions of secondary aminonaphthols, aminoquinolinols and aminoisoquinolinols and conformational analysis of the new naphth[1,3]oxazino-heterocycles..

3.2. [4+2] Cycloaddition reactions of cyclic imines and o-QMs formed by various aminonaphthols 
3.2.2. Reactions of 6,7-dihydrothieno[3,2-c]pyridine and various aminonapthols

3.2.3. Reactions of $(4 \mathrm{a} S, 8 \mathrm{a} S)-4 \mathrm{a}, 5,6,7,8,8 \mathrm{a}$-hexahydro-2-quinoxalinone and various aminonapthols. 38

3.2.4. Conformational analysis of the new naphth[1,3]oxazino[2,3-a] heterocycles 41

4. SUMMARY .44

5. ACKNOWLEDGEMENTS .46

6. REFERENCES .47

7. ANNEX 52 


\section{PUBLICATIONS}

\section{Papers related to the thesis}

I. Petra Barta, István Szatmári, Ferenc Fülöp, Matthias Heydenreich, Andreas Koch, Erich Kleinpeter

Synthesis and stereochemistry of new naphth[1,3]oxazino[3,2-a]benzazepine and naphth[1,3] oxazino[3,2-e] thienopyridine derivatives

Tetrahedron 2016, 72, 2402-2410. DOI: 10.1016/j.tet.2016.03.058

IF: 2.651

II. István Szatmári, Petra Barta, Antal Csámpai, Ferenc Fülöp

Synthesis and detailed conformational analysis of new naphthoxazino[2,3-a]benz $[c]$

azepine and naphthoxazino[2,3- $a$ ]thieno[3,2-c]pyridine derivatives

Tetrahedron 2017, 73, 4790-4804. DOI: 10.1016/j.tet.2017.06.060

IF: 2.651

III. István Szatmári, Petra Barta, Gábor Tóth, Attila Balázs, Judit Halász, Ferenc Fülöp

Synthesis and conformational behaviour of novel enantiomeric naphthoxazino-quinoxalinone derivatives

Eur. J. Org. Chem. 2017, 5537-5545. DOI: 10.1002/ejoc.201700699

IF: $\mathbf{2 . 8 3 4}$

IV. Petra Barta, Ferenc Fülöp, István Szatmári

Mannich base connected syntheses mediated by ortho-quinone methides

Beilstein J. Org. Chem. 2018, 14, 560-575. DOI:10.3762/bjoc.14.43

IF: 2.3 


\section{Conference lectures}

V. Barta Petra

Új, benzazepinnel és tienopiridinnel kondenzált naftoxazin-származékok szintézise

A Szegedi Ifjú Szerves Kémikusok Támogatásáért Alapítvány elöadóülése

Szeged, 2015. április 29.

VI. Barta Petra, Szatmári István és Fülöp Ferenc

Új naftoxazino[2,3-a]benz[c]azepin-, valamint naftoxazino[2,3- $a$ ]tieno[3,2-c]piridinszármazékok szintézise

MTA Heterociklusos és Elemorganikus Kémiai Munkabizottság ülése

Balatonszemes, 2015. május 27-29.

VII. Barta Petra, Szatmári István és Fülöp Ferenc

Potenciális farmakológiai aktivitással rendelkező naftoxazinokinoxalinon-származékok szintézise

Gyógyszerkémiai és Gyógyszertechnológiai Szimpózium '16

Herceghalom, 2016. szeptember 15-16.

VIII. Barta Petra, Szatmári István, Csámpai Antal és Fülöp Ferenc

A 3-hidroxiizokinolin finomhangolt reaktivitása

MTA Heterociklusos és Elemorganikus Kémiai Munkabizottság ülése

Balatonszemes, 2017. május 15-17.

IX. István Szatmári, Petra Barta and Ferenc Fülöp

Synthesis of new naphthoxazine-fused heterocycles via the modified Mannich reaction

15th Tetrahedron Symposium, Challenges in Bioorganic and Organic Medicinal Chemistry 24-27th June, 2014 London, UK, Abstr.: P2.33

X. Petra Barta, István Szatmári and Ferenc Fülöp

Synthesis of new naphthoxazino-benzazepine and -thienopyridine derivatives

16th Blue Danube Symposium on Heterocyclic Chemistry

14-17th June, 2015 Balatonalmádi, Abstr.: P5

XI. Petra Barta, István Szatmári and Ferenc Fülöp

Synthesis and conformational analysis of enantiomeric naphthoxazino-quinoxalinone derivatives

25th International Symposium: Synthesis in Organic Chemistry

17-20th July, 2017 Oxford, UK, Abstr.: P55 


\section{INTRODUCTION AND AIMS}

The Mannich reaction is an important one-pot, multicomponent, C-C bond formation reaction that is widely used in the synthesis of many biologically active and natural compounds ${ }^{1-5}$. Originally, the Mannich product is formed through a three-component reaction involving a $\mathrm{C}-\mathrm{H}$ acid, formaldehyde and a secondary amine. Nowadays one of its special variations called modified Mannich reaction gained ground in which the $\mathrm{C}-\mathrm{H}$ acid is replaced by electron-rich aromatic compounds such as 1- or 2-naphthol as the active hydrogen source ${ }^{6}$. At the beginning of the $20^{\text {th }}$ century, Mario Betti reported the synthesis of 1-aminobenzyl-2-naphthol starting from ammonia, benzaldehyde and 2-naphthol. This protocol is known as the Betti reaction and the compound formed as Betti base ${ }^{7-11}$. Several examples have been published to extend the reaction and synthesize variously substituted aminonaphthol derivatives ${ }^{12}$. Their relatively easy accessibility and promising biological properties have brought the chemistry of these compounds again to the forefront of pharmacological research.

The formation of the aminonaphthol product can be explained by two mechanisms. According to one possibility, first a Schiff base is formed in the reaction of the amine and the aldehyde and then it reacts further with 2-naphthol in the second nucleophilic addition step. The other theory assumes the formation of an ortho-quinone methide (o-QM) intermediate by the reaction of 2-naphthol and benzaldehyde. The driving force of the transformation is rearomatization, which occurs in the second step in the nucleophilic addition of the amine component. As an extention of this modified Mannich reaction, 1- and 2-naphthol and their $N$ containing analogues were reacted with a wide range of cyclic amines to furnish various aminonaphthol derivatives. These processes followed by ring-closure reactions lead to the formation of naphth[1,2$e][1,3]$ oxazino[3,4-c] [1,3] benzoxazines $^{13,14}$, naphth[1,2-e][1,3] oxazino[3,4-c]quinazolines ${ }^{15}$, naphth[1,2$e][1,3]$ oxazino[3,2-c]quinazolin-13-ones ${ }^{16}$ and naphth[1,2-e][1,3]oxazino[4,3- $\left.a\right]$ isoquinoline derivatives ${ }^{17}$.

My $\mathrm{PhD}$ work has been planned to accomplish two major goals. The first was to examine the scope and limitations of this latter reaction to achieve napthoxazino-benzazepines, -thienopyridines and quinoxalinones. We have designed the reaction of cyclic imines with electron-rich aromatic compounds such as 1- or 2-naphthol and in some cases, $N$-containing naphthol analogues 5-hydroxyisoquinoline or 6-hydroxyquinoline. The isolated secondary aminonaphthols, aminoquinolinols or aminoisoquinolinols then undergo a cyclization reaction with formaldehyde affording the desired naphthoxazine-fused polyheterocycles. 


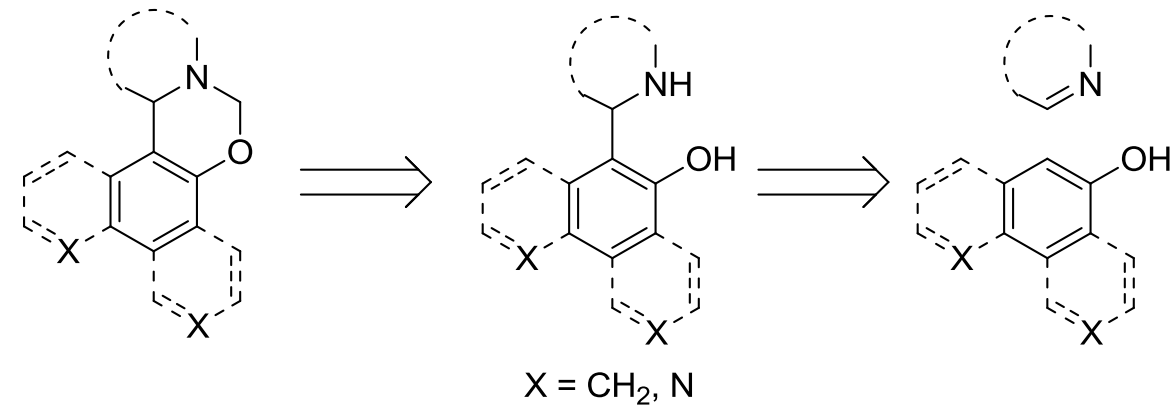

The class of $o$-QMs is known as short-lived species that play important roles as key intermediates in numerous synthetic pathways ${ }^{18-22}$. One of the first examples of the [4+2] cycloaddition reaction between $o$-QMs formed by aminoalkylnaphthols and partially saturated cyclic imines was published by our group when a serendipitous reaction led to the formation of 9,10-dimethoxynaphth[1,2-e][1,3] oxazino[2,3-a]isoquinolines by the reaction of 1- $\alpha$ aminobenzyl-2-naphthol and 6,7-dimethoxy-3,4-dihydroisoquinoline ${ }^{23}$.

The second goal was to investigate the applicability of various cyclic imines such as 4,5dihydro-3H-benz[c]azepine, 6,7-dihydrothieno-[3,2-c]pyridine and enantiomeric (4aS,8aS)4a,5,6,7,8,8a-hexahydro-2-quinoxalinone in this [4+2] cycloaddition reaction mentioned above. In addititon, we wanted to extend the syntheses by the application of 1-aminoalkyl-2-naphthols and 2-aminoalkyl-1-naphthols with varied substitution patterns to synthesize a wide range of novel naphthoxazine-fused polyheterocycles.

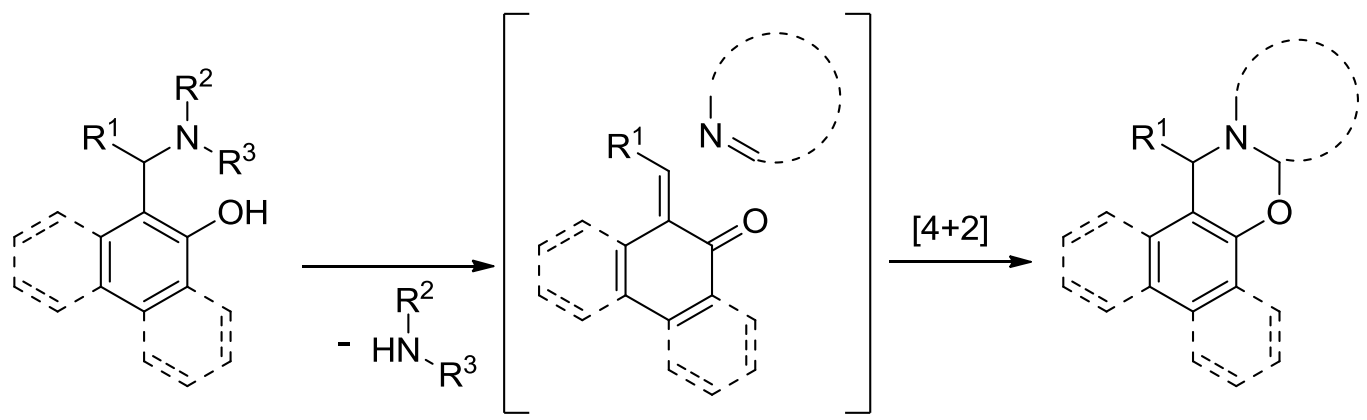




\section{LITERATURE BACKGROUND}

\section{1. ortho-Quinone methide mediated, Mannich base connected syntheses}

\subsubsection{Formation of Mannich bases via $o$-QM intermediates}

\subsubsection{Synthesis of amidoalkylnaphthols}

The synthesis of amidoalkylnaphthols has recently been inestigated from numerous aspects $^{24}$. This indicates the importance of this reaction because 1-amidoalkyl-2-naphthols can easily be converted to important biologically active 1-aminoalkyl-2-naphthol derivatives by a simple amide hydrolysis. To optimize reaction conditions considering environmental and economical aspects, several conditions were examined testing a wide range of catalysts, microwave-assisted reactions or solvent-free conditions. The related procedures were carried out as one-pot multicomponent reactions without the isolation of the intermediates formed. Therefore, with the application of nontoxic, readily available, inexpensive reagents and reusable catalysts, both time and energy are saved.

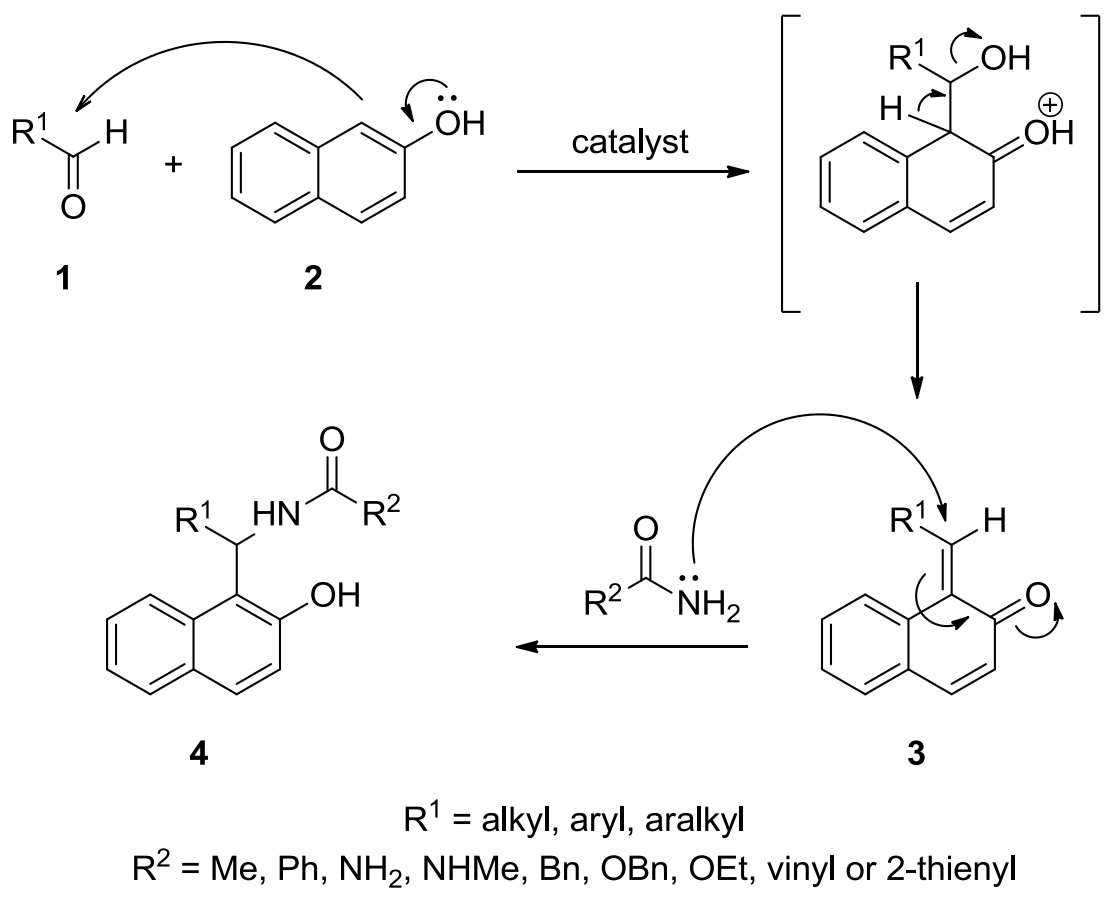

Scheme 1. Formation of amidoalkylnaphthols 4 via $o$-QM intermediate 
The plausible mechanism of the formation of amidoalkylnaphthols is shown in Scheme 1 . First, the reaction between the aldehyde and 2-naphthol, induced by the catalyst, leads to the generation of $o-\mathrm{QM}$ intermediate 3 that reacts further with the amide component to form the desired 1-amidoalkyl-2-naphthol derivatives. This second step can also be considered as a nucleophilic addition of the amide to the $o$-QM component.

Lately, the application of nanocatalysts in this reaction has attracted considerable attention since nanocatalysts, in general, are stable and recyclable and they exhibit higher activity compared to conventional catalysts. A few examples are listed here. Aluminatesulfonic acid nanoparticles proved to be efficient under neat conditions for the synthesis of 1-amidoalkyl-2-naphthols ${ }^{25}$. Zali et al. carried out this synthesis applying nano-sulfated zirconia $^{26}$, Borhade et al. used $\mathrm{PbS}$ nanoparticles ${ }^{27}$, while Safari et al. applied magnetic nanoparticle-supported sulfuric acid ${ }^{28}$. All methods give the desired amidoalkylnaphthols in 80-90\% yields. Zolfigol et al. successfully applied 1-methylimidazolium tricyanomethanide as the first nanostructured molten salt ${ }^{29}$. The catalyst gave remarkable results at room temperature in short reactions (5-30 minutes) in 90-96\% yields. In comparison, reactions performed by the application of tin dioxide nanoparticles, required longer reaction times and gave lower yields indicating that the molten salt catalyst is more effective ${ }^{29}$.

Ionic liquids have also been of interest recently because of their ,green chemistry” values including high thermal stability, reusability and non-inflammability. Hajipour et al. reported the one-pot synthesis of 1-amidoalkyl-2-naphthols catalysed by $N$-(4-sulfonic acid)-butyltriethylammonium hydrogen sulfate as Brønsted acidic ionic liquid ${ }^{30}$. In addition, ethylammonium nitrate $^{31}$, a sulfonic acid-functionalized benzimidazolium-based supported ionic liquid catalyst ${ }^{32}$ and carboxyl-functionalized benzimidazolium-based ionic liquids ${ }^{33}$ also proved to be efficient in the reaction.

Safari et al. combined the benefits of using magnetic nanoparticles and ionic liquids by the application of magnetic $\mathrm{Fe}_{3} \mathrm{O}_{4}$ nanoparticles functionalized with 1-methyl-3-(3trimethoxysilylpropyl)- $1 H$-imidazol-3-ium acetate as catalyst ${ }^{34}$. Syntheses carried out by conventional heating at $100{ }^{\circ} \mathrm{C}$ required long reactions affording yields of 82-97\%. In contrast, they achieved excellent $90-98 \%$ yields in short reaction times under mild conditions by the application of sonication.

In earlier publications, the use of Lewis and Brønsted acid catalysts is also found to be effective in the synthesis of 1-amidoalkyl-2-naphthols. The use of $p$-toluenesulfonic acid ${ }^{35}$, montmorillonite $\mathrm{K} 10^{36}$, Indion- $130^{37}$, iodine ${ }^{38}$, potassium dodecatungstocobaltate ${ }^{39}$, silica- 
supported perchloric acid ${ }^{40-42}$ and sulfuric acid ${ }^{43}$, chlorosulfonic acid ${ }^{44}$, sodium hydrogen sulfate ${ }^{45}$, ferric(III) hydrogen sulfate ${ }^{46}$, strontium(II) triflate $^{47}$, copper-exchanged heteropoly acids ${ }^{48}$ and wet cyanuric acid ${ }^{49}$ was also tested. These methods suffer from a number of drawbacks, such as strong acidic media, high temperature, and prolonged reactions. Furthermore, yields are often not satisfactory.

To avoid the disadvantages of previous strategies, Samant et al. reported an ultrasoundpromoted condensation catalysed by sulfamic $\operatorname{acid}^{50}$. Syntheses were carried out both in dichloroethane (DCE) and under neat conditions. Low $\left(28-30{ }^{\circ} \mathrm{C}\right)$ temperature was required and products were formed in short reactions in up to $94 \%$ yields. Shinde et al. also published iodine catalysis carried out at room temperature in $\mathrm{DCE}^{51}$. Whereas long reaction times were needed in this process, good yields could be achieved under mild conditions.

In additional publications, phosphorus pentoxide ${ }^{52}$, silica-supported phosphorus pentoxide ${ }^{53}$, $N, N, N^{\prime}, N^{\prime}$-tetrabromobenzene-1,3-disulfonamide ${ }^{54}$, 1-methyl-3-(2-(sulfoxy)ethyl)-1H-imidazol-3ium chloride ${ }^{55}$, succinic acid ${ }^{56}$, tannic acid $^{57}, p$-nitrobenzoic acid ${ }^{58}$, a carbon-based solid acid ${ }^{59}$, citric acid $^{60}$, sulfanilic acid ${ }^{61}$, bismuth(III)-nitrate pentahydrate ${ }^{62}, 1$-hexanesulfonic acid sodium salt $^{63}$, zirconyl triflate ${ }^{64}$, sulfonated carbon ${ }^{65}$, MCM-41- $N$-propylsulfamic acid ${ }^{66}$, polyphosphate ester $^{67}$ and amberlite IR- $120^{68}$ were used as catalysts. These latest strategies provide efficient syntheses under mild conditions without using harsh chemicals. Furthermore, to accelerate the reactions, the application of microwave irradiation or sonication is also preferred to conventional heating methods.

\subsubsection{Aminoalkylphenols}

The mechanism of the formation of phenolic Mannich bases is similar to that discussed above for the synthesis of amidoalkylnaphthols. First, the phenol component reacts with the aldehyde to form the $o$-QM intermediate, which reacts in a nucleophilic addition step with the amine component resulting in aminoalkylphenol derivatives. A few examples are summarized in Table 1. An important difference, however, must be noted. In the case of aminonalkylnaphthols, the $o$-QM intermediate partially remains aromatic while the formation of phenolic $o$-QMs leads to the loss of the aromaticity of the only aromatic ring present. This results in differences in both the formation and stability of $o-\mathrm{QM}$.

Grimaud et al. synthesized Mannich bases starting from $N$-benzylpiperazine, various aldehydes and substituted phenols ${ }^{69}$. The intermediate Mannich adducts $(\mathbf{8 a - i})$ were then reacted with 5,5-dimethylcyclohexane-1,3-dione or 1-methyl-1H-indole in the presence of lithium 
perchlorate as catalyst affording the formation of new 3,3-dimethyl-2,3,4,9-tetrahydro- $1 \mathrm{H}$ xanthen-1-ones and 3-substituted indoles. The process was then extended to isocyanides and new aminobenzofurans formed via [4+1] cycloaddition were isolated.

Bharate et al. reported ortho-amidoalkylation of phenols in which a tandem Knoevenagel condensation occurs through $o$-QM followed by the formation of an unstable oxazine intermediate ${ }^{70}$. The same research group later published a similar reaction extended by various lactams carried out in trifluoroacetic acid in water ${ }^{71}$. As reported in both papers, Mannich bases formed (9a-t) were isolated in good yields. Plausible reaction pathways were described and the energetic values of the transition states were calculated.

Table 1. Formation and substrate scope of phenolic Mannich bases

\begin{tabular}{|c|c|c|c|c|c|}
\hline 5 & 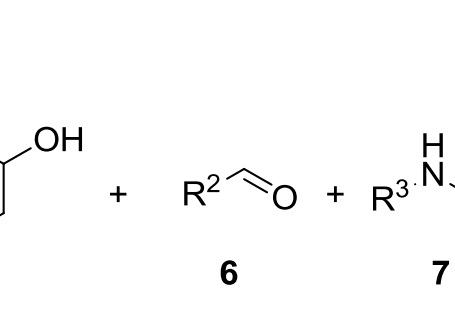 & & $\mathrm{CO}^{\mathrm{HN}_{\mathrm{O}}^{\mathrm{P}^{4}}} \mathrm{R}^{3}$ & 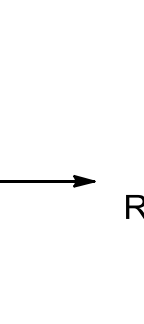 & $\underbrace{R_{1}^{3}}_{8-10}$ \\
\hline Entry & $\mathrm{R}^{1}$ & $\mathrm{R}^{2}$ & $\mathrm{R}^{3}-\stackrel{\mathrm{H}}{\mathrm{N}}-\mathrm{R}^{4}$ & Product & Reference \\
\hline 1 & 4-Me, 4-COOMe & $\begin{array}{c}\mathrm{Ph}, 4-\mathrm{MeOPh}, \\
\text { 4- } \mathrm{NO}_{2} \mathrm{Ph}, 3-\mathrm{CF}_{3} \mathrm{Ph}, \\
\text { 2-All-O-Ph }\end{array}$ & IN & 8a-i & [69] \\
\hline 2 & 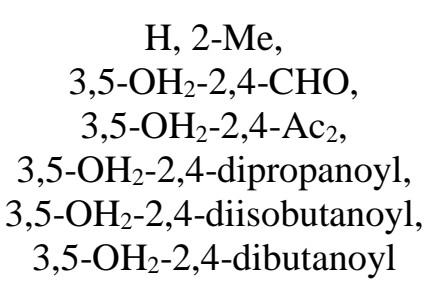 & $\mathrm{H}$ & $\prod_{\mathrm{O}}^{\left(\mathrm{CH}_{2}\right)_{n}} n=1-3$ & $9 a-t$ & {$[70,71]$} \\
\hline 3 & $\begin{array}{c}\text { 3-Cl, 2-NO }{ }_{2}, 4-\mathrm{OMe}, 4- \\
\mathrm{NO}_{2}, 4-\mathrm{Cl}, 2,4-\mathrm{Cl}_{2}\end{array}$ & $\begin{array}{c}\text { 4- } \mathrm{BrPh}, 4-\mathrm{NO}_{2} \mathrm{Ph}, \\
\text { 4-ClPh, 4-OMePh, } \\
\text { 2,3- } \mathrm{Me}_{2} \mathrm{Ph} \\
\text { 4-t- }-\mathrm{BuPh}\end{array}$ & & 10a-m & {$[72]$} \\
\hline
\end{tabular}

In one of the latest publications with respect to this topic, Priya et al. disclosed the synthesis of a wide range of novel 2-[(benzo[d]thiazol-2-ylamino(phenyl)methyl]phenols 10a-m ${ }^{72}$. 
They reacted 2-amino-1,3-benzothiazoles, various aldehydes and substituted phenols in the presence of $\mathrm{ZnCl}_{2}$ as catalyst.

\subsubsection{Reactions of $o$-QMs formed by Mannich bases}

As the formation of Mannich bases can be explained by the generation of an $o$-QM intermediate followed by the nucleophilic addition of the amine component, the reverse reaction with the corresponding nucleophile is also feasible. Mechanistically, the Mannich adduct generates an $o-\mathrm{QM}$ via the loss of an amine, then this reactive intermediate reacts with the nucleophile (dienophile) species in various reactions to form a wide range of heterocyclic compounds.

\subsubsection{Reactions with $\mathrm{C}=\mathrm{C}$ dienophiles}

Reactions of $o$-QMs with different $\mathrm{C}=\mathrm{C}$ dienophiles are listed in Table 2. One of the first examples was published by Saito et al. who generated $o$-QMs starting from Mannich bases by low-energy UV irradiation in aqueous acetonitrile ${ }^{73}$. In the presence of a large excess of ethyl vinyl ether as $o$-QM trapping agent, they isolated several 2-ethoxychromane derivatives (12). However, yields as low as $36 \%$ were found in some cases.

Osyanin et al. reported an efficient reaction of quaternary ammonium salt of Mannich bases with malononitrile catalysed by 1,8-diazabicyclo[5.4.0]undec-7-ene (DBU) ${ }^{74}$. It is known that the use of quaternary ammonium salts offers the easier removal of the amino residue and, therefore, trapping the transient electrophilic species at lower temperature. Carrying out the reactions in protic solvents such as $\mathrm{H}_{2} \mathrm{O}$ or $\mathrm{EtOH}$ at $100{ }^{\circ} \mathrm{C}$, the desired products were formed in short reactions (1-20 $\mathrm{min}$ ) and chromene-2-carbonitriles 13-16 were isolated in 61-88\% yields.

$o$-QMs derived from Mannich adducts also appear to be key intermediates in the syntheses of biologically active natural compounds. Wilson et al. successfully achieved the total synthesis of xyloketals 17-18, including cycloaddition of substituted dihydrofurans and 1-(2,4-dihydroxy-3(morpholinomethyl)phenyl)ethanone via $o-\mathrm{QM}$ intermediates ${ }^{75}$. The Osyanin group reported the synthesis of Uvaria scheffleri alkaloids espintanol and ( \pm )-schefflone starting from 6((dibenzylamino)methyl)-3-isopropyl-2,4-dimethoxyphenol. The $o$-QM formed could also be trapped by benzotriazole or 3-(dimethylamino)-5,5-dimethylcyclohex-2-en-1-one resulting in azaMichael product 19 and tetrahydro- $1 H$-xanten-1-one 20, respectively ${ }^{76}$. Interestingly, in the formation of 19, benzotriazole as $N$-nucleophile reacted with the generated $o$-QM. Starting from 
phenolic Mannich bases and 3-dimethylamino-2-cyclohexen-1-ones, the synthesis of 2,3,4,9tetrahydro- $1 H$-xantene-1-ones has been published by the same research group. The synthetic protocol was then extended to isolate 8,9,10,12-tetrahydro-11H-benzo[a]xanthen-11-ones 21 starting from 2-naphthol and $1 H$ - $\beta$-carbolin-1-one Mannich bases or their quaternary derivatives ${ }^{77}$. Although high temperature was needed (reflux at $153{ }^{\circ} \mathrm{C}$ for 4 hours), the desired products were isolated in good (53-91\%) yields. The Osyanin group also reported better results with the use of polyheterocyclic initial compounds. This can be explained by a dearomatisation step taking place in the transformation of phenolic Mannich bases leading to the disappearance of the only aromatic ring. In one of their recent publications ${ }^{78}$, they elaborated a simple route to 1,2dihydronaphtho[2,1-b]furan and 2,3-dihydrobenzofurans via base-induced desamination. They also reported the development of a simple, general route to 2,3-dihydrobenzofurans 22 starting from phenolic Mannich bases. The syntheses were also extended to 2-naphthol Mannich bases as initial compounds affording C-2-substituted 1,2-dihydronaphtho[2,1-b]furans.

Bray et al. reacted ortho-hydroxybenzylamines with 2,3-dihydrofuran and $\gamma$-methylene- $\gamma$ butyrolactone in DMF at $130{ }^{\circ} \mathrm{C}^{79}$. This method could successfully be applied in the synthesis of the spiroketal core of rubromycins 23-24.

Table 2. Reactions of $o$-QMs with different dienophile species

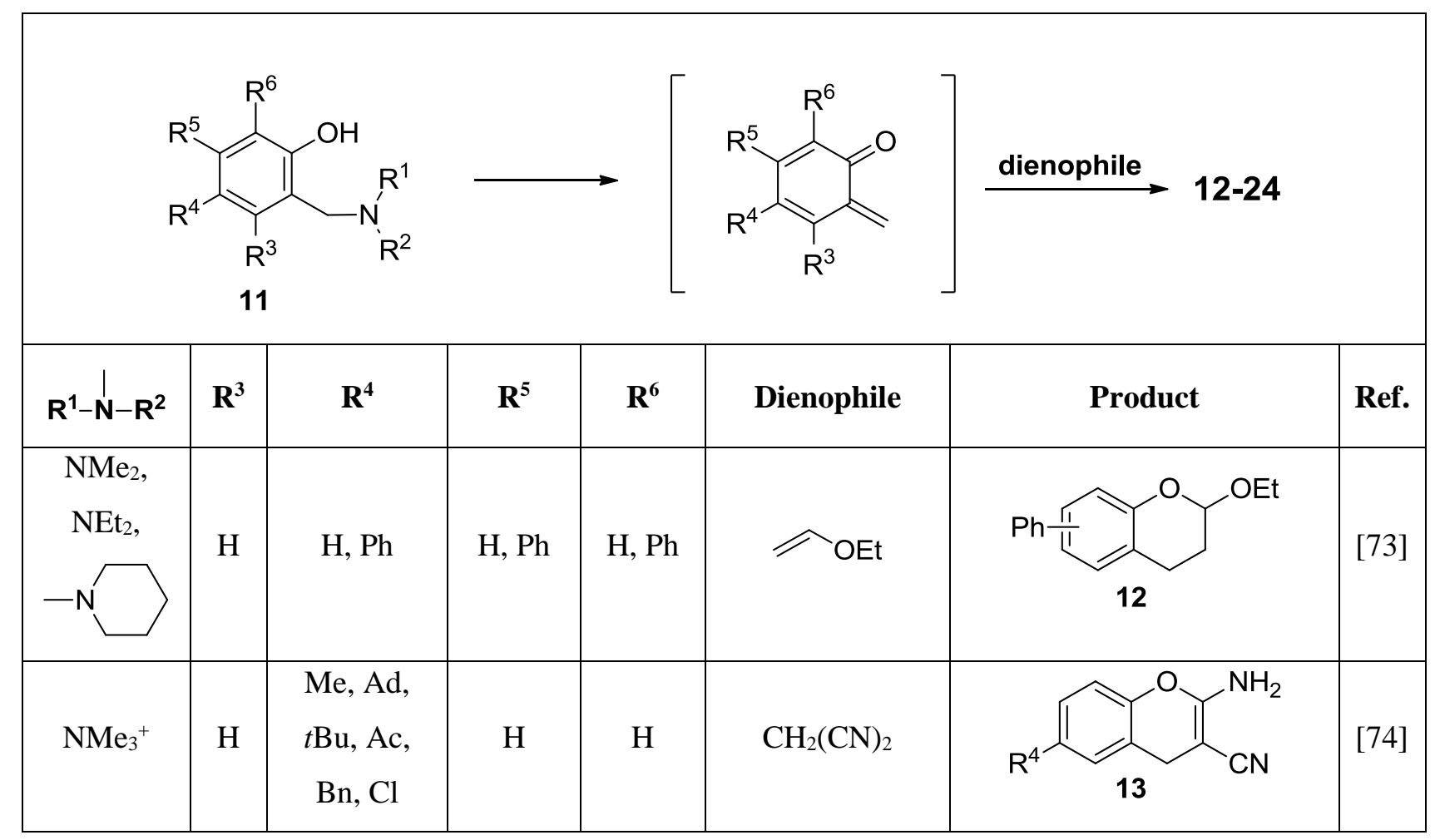




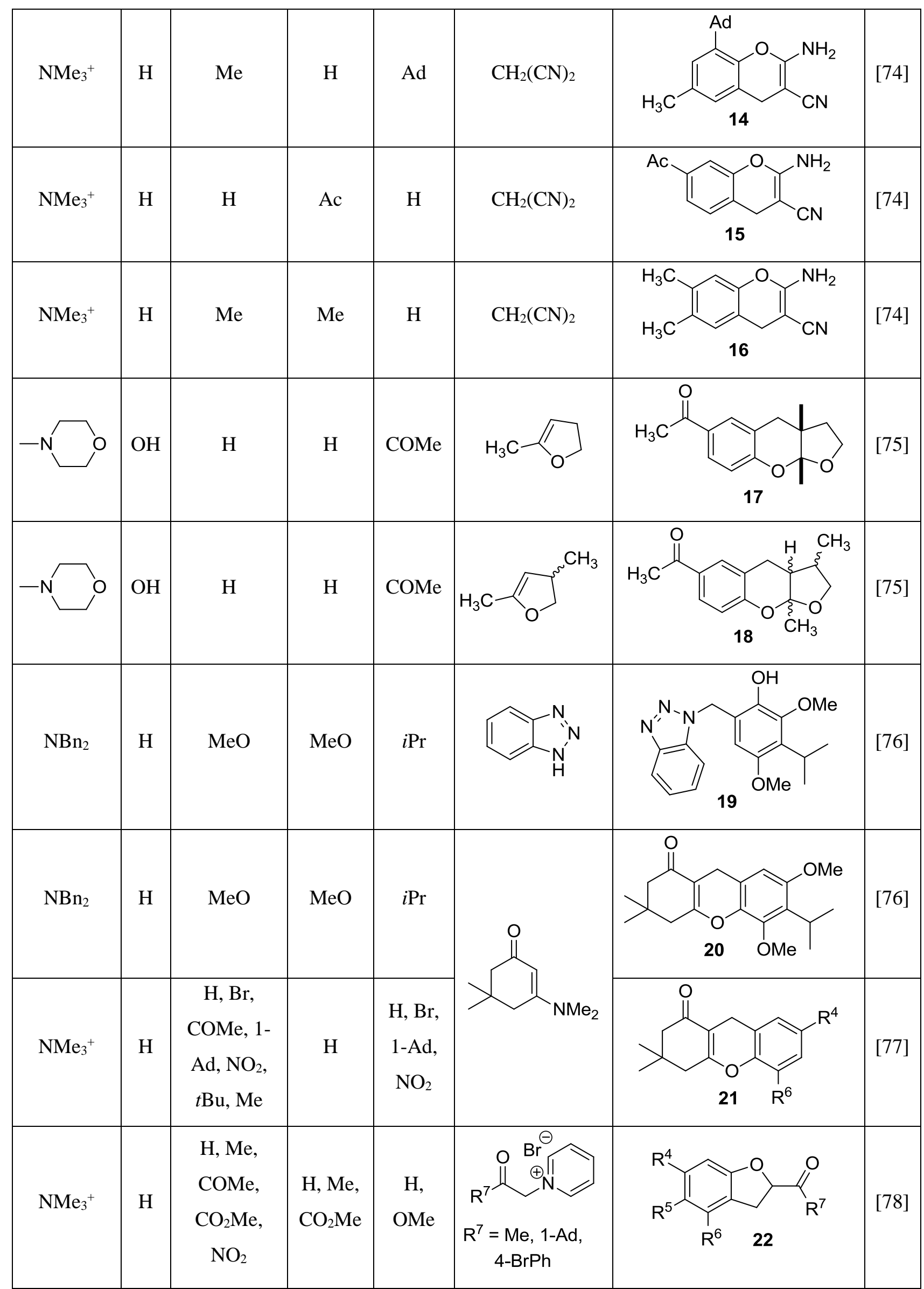




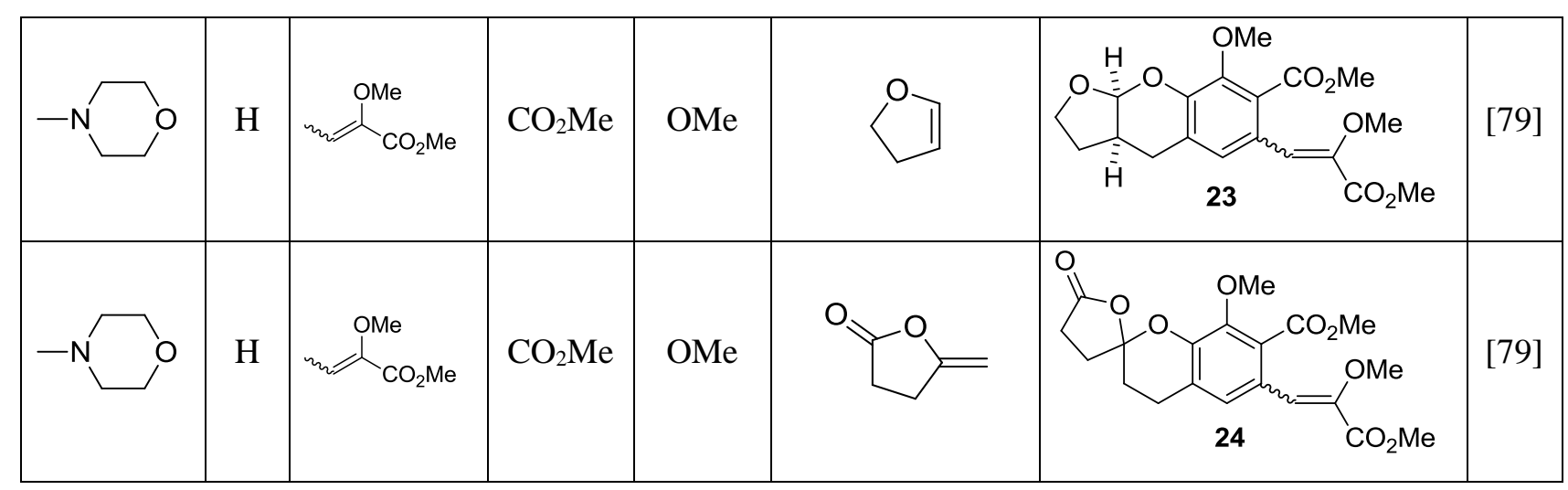

Starting from 2-naphthol, 2,2-disubstituted-3-hydroxypropanals and cyclic secondary amines, Jha et al. achieved the synthesis of 2,2-dialkyl-3-dialkylamino-2,3-dihydro- $1 H$ naphtho[2,1-b]pyrans under solvent-free conditions using $p$ TSA as catalyst ${ }^{80}$. It is important to note that during the reaction, 2,2-disubstituted-3-hydroxypropanals (25) decompose to formaldehyde and 2,2-disubstituted acetaldehydes 27. Formaldehyde, as a non-enolizable compound is more likely to give Mannich base product 29. In contrast, enolizable 2,2disubstituted aldehydes easily form enamines 30 that undergo cycloaddition with electrondeficient $o$-QMs giving 2,2-dialkyl-3-dialkylamino-2,3-dihydro- $H$-naphtho[2,1-b]pyrans (31). A plausible mechanism is depicted in Scheme 2.<smiles>[R]C([R])(C=O)CO</smiles><smiles>[R]C=[R]([R])[R]</smiles>

28

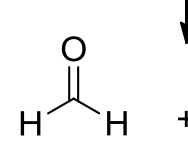

26<smiles>[R]C([Hg]C)C(=O)OC</smiles>

$27 \mathrm{R}^{1}$<smiles>[R]CC[R]([R])=C</smiles>

30<smiles>Oc1ccc2ccccc2c1</smiles><smiles>[R]N([R])Cc1c(O)ccc2ccccc12</smiles>

29<smiles>[R]/C(=C/N([R1])[R])CCCCC</smiles><smiles>[R]N([R])C1Oc2ccc3ccccc3c2CC1([R])[R]</smiles>

Scheme 2. Proposed mechanism of the formation of 2,2-dialkyl-3-dialkylamino-2,3-dihydro- $1 H$ naphtho[2,1-b]pyrans 
Table 3. Dimerization of $o-\mathrm{QMs}$

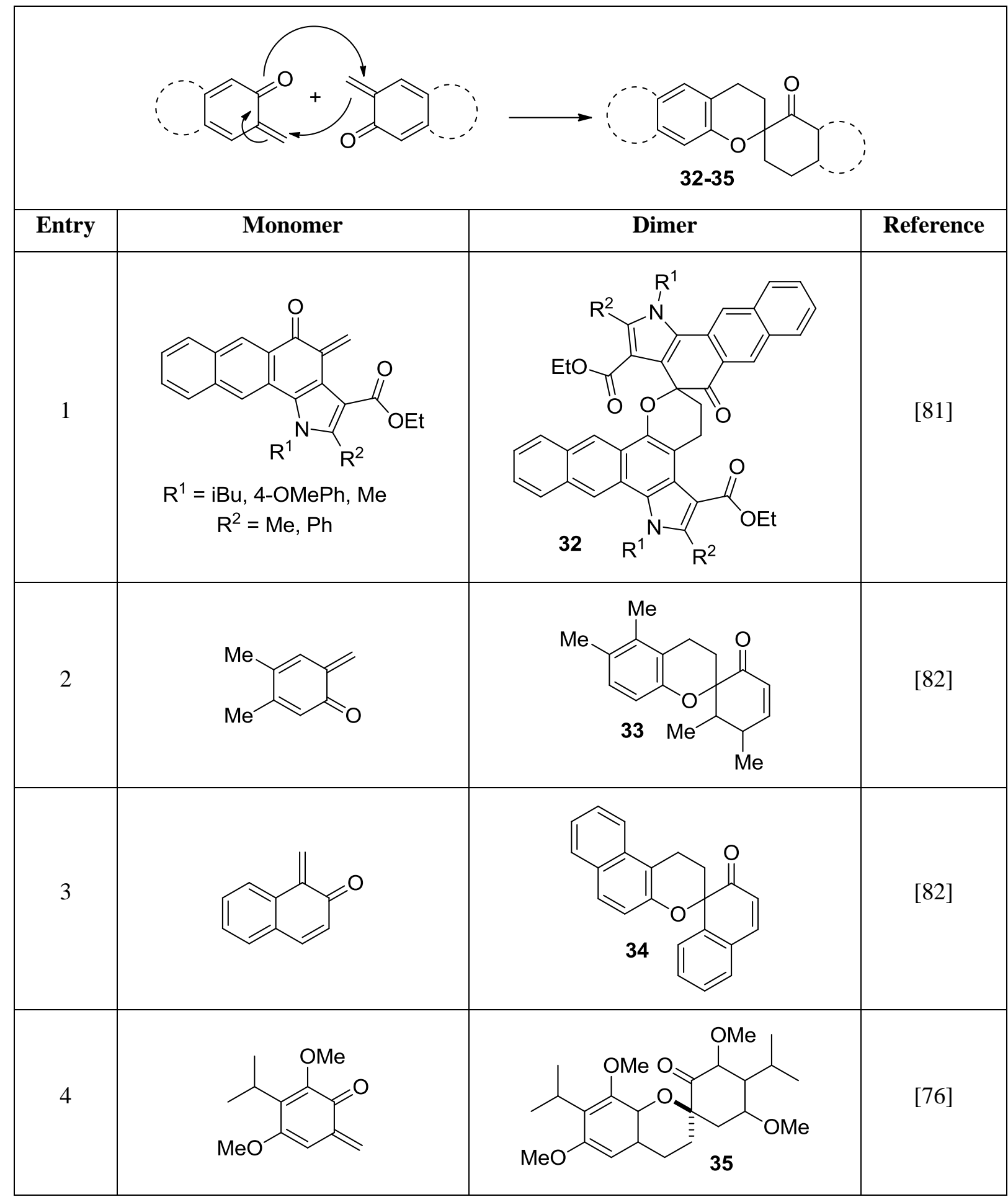

$o$-QMs are also known to undergo oligomerization in the absence of dienophiles and nucleophiles via an oxo-Diels-Alder protocol (Table 3). During the syntheses of 1,4,9,10antradiquinones with potential antitumor activity, Kucklaender et al. isolated new spiro derivatives $\mathbf{3 2}^{81}$. These latter spirocyclic dimers were formed in a Diels-Alder dimerization process by heating the corresponding Mannich bases under reflux in dichloromethane for 2 hours. 
In the synthesis of 3,4-dihydro-2-aryl-2H-benzo[f]chromenes and 2-aryl-6,7dimethylchromans starting from substituted styrenes and 1-dimethylaminomethyl-2-naphthol or 2dimethylaminomethyl-4,5-dimethylphenol, Bilgic et al. detected the formation of both dimers $\mathbf{3 3}$ and 34 of $o$-QMs formed by the thermal desamination of the initial compounds ${ }^{82}$.

However, a few publications report this phenomenon as an advantageous reaction rather than the formation of unexpected side products. As mentioned above $\mathrm{e}^{76}$, Osyanin et al. reported the synthesis of Uvaria scheffleri alkaloid ( \pm )-schefflone. In this publication, the dimerization of the $o$-QM resulting in intermediate $\mathbf{3 5}$ is a key step in the synthesis of the final natural trimer compound.

\subsubsection{Reactions with $\mathrm{C}=\mathrm{N}$ dienophiles}

The preparation of novel $o-\mathrm{QM}$-condensed polyheterocycles is a relatively new area of Mannich-base chemistry. Our research group has also been interested in cycloaddition reactions of $o$-QMs generated from Mannich adducts 36, when a serendipitous reaction occurred. Namely, the formation of new naphthoxazino-isoquinoline derivatives 37 was observed in the reaction of 1aminoalkyl-2-naphthols and 6,7-dimethoxy-3,4-dihydroisoquinoline under neat conditions ${ }^{23}$. At the same time, Osyanin and coworkers reported the same reaction extended by various substituted aminonaphthols ${ }^{83}$. Achieving the syntheses in ethanol at $78^{\circ} \mathrm{C},[4+2]$ cycloaddition took place between the $o$-QM generated from the corresponding aminonaphthol as diene component and cyclic imines playing the role of heterodienophiles. (Scheme 4)<smiles>[R1]NC([R])c1c(O)c2ccccc2c2ccccc12</smiles><smiles>[R]c1cc2c(cc1[R])C1Oc3c(c4ccccc4c4ccccc34)C([R])N3CCC1=C23</smiles>
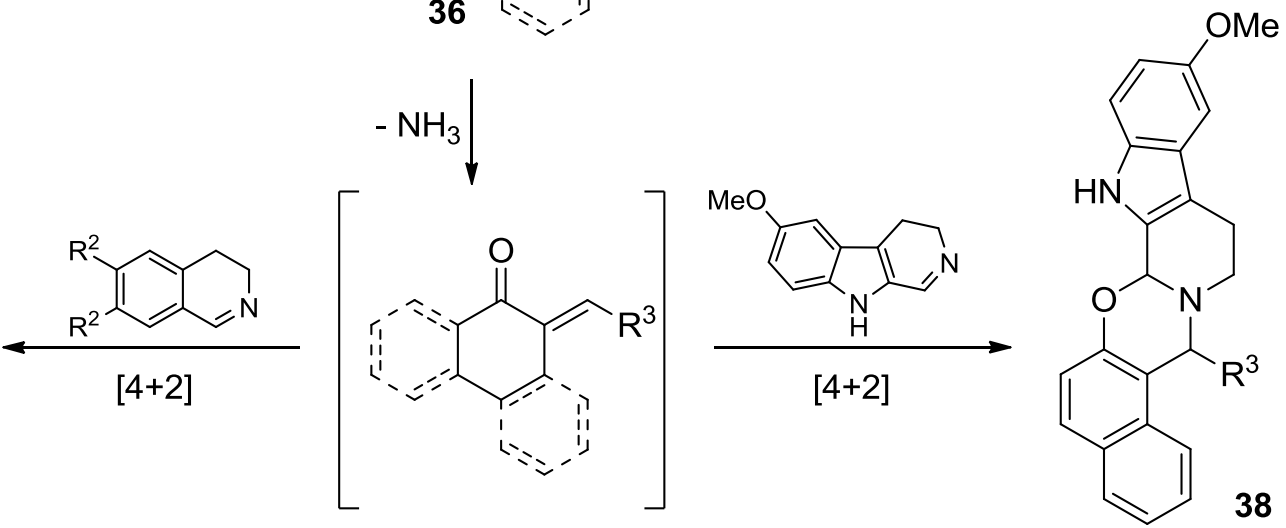

$$
\begin{gathered}
\mathrm{R}^{1}=\mathrm{H} ; \mathrm{Me} \quad \mathrm{R}^{2}=\mathrm{H} ; \text { OMe } \\
\mathrm{R}^{3}=\mathrm{H} ; \mathrm{Ph} \text {; 1-Nph; 2-Nph, 1-benzyl-1H-imidazol-5-yl, 2-thienyl }
\end{gathered}
$$

Scheme 4. [4+2] Cycloaddition reactions between aminonaphthols and cyclic amines 
[4+2] Cycloadditions between cyclic imines and $o$-QMs derived from Mannich bases could also be successfully applied in the syntheses of natural alkaloid-like compounds $\mathbf{3 8}$. Osyanin et al. reported the preparation of rutaecarpine and evodiamine, the 14-oxa analogues of Evodia rutaecarpa alkaloids, starting from 6-methoxy-4,9-dihydro- $\beta$-carboline and various substituted 1aminoalkyl-2-naphthols ${ }^{84}$. (Scheme 4)

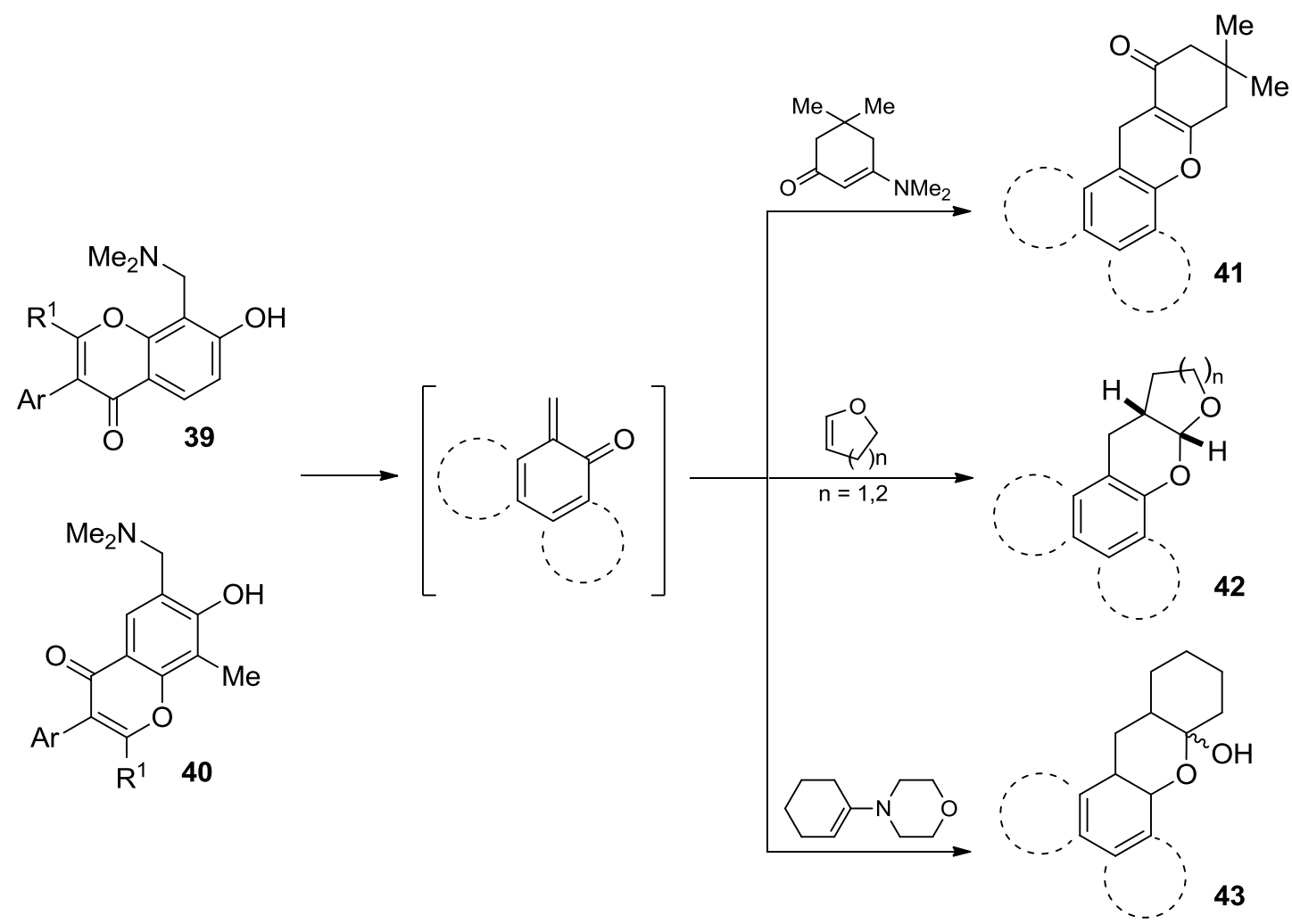

Scheme 5. Cycloadditions of $o$-QMs derived form isoflavonoids and various dienophiles

Watt et al. achieved the regioselective condensation of bis( $N, N$-dimethylamino)methane with various hydroxyisoflavonoids to synthesize C-6- and C-8-substituted isoflavonoids 39 and 40 in a Mannich-type reaction ${ }^{85}$. These $o$-QM precursors generated by thermal elimination of dimethylamine were then reacted with varied cyclic dienophiles to give various inverse electrondemand Diels-Alder adducts. In the case of $\mathbf{4 2}$, the cis-fused ring system was found to be similar to bioactive xyloketals isolated from fungi 41-43. (Scheme 5)

\subsubsection{Reactions with electron-rich aromatic compounds}

The formation of aza-o-QMs is also possible if the initial phenolic Mannich base bears an aromatic moiety on its benzylic carbon atom. Rueping et al. recently performed reactions between 
aza- $o$-QMs generated in situ from $\alpha$-substituted ortho-aminobenzyl alcohols (44) and substituted indoles catalysed by $N$-triflylphosphoramides (NTPAs) ${ }^{86}$. (Scheme 6) The process provided new C-2- and C-3-functionalized indole polyheterocycles $\mathbf{4 5}$ and $\mathbf{4 6}$ in good yields with 90-99\% ee.

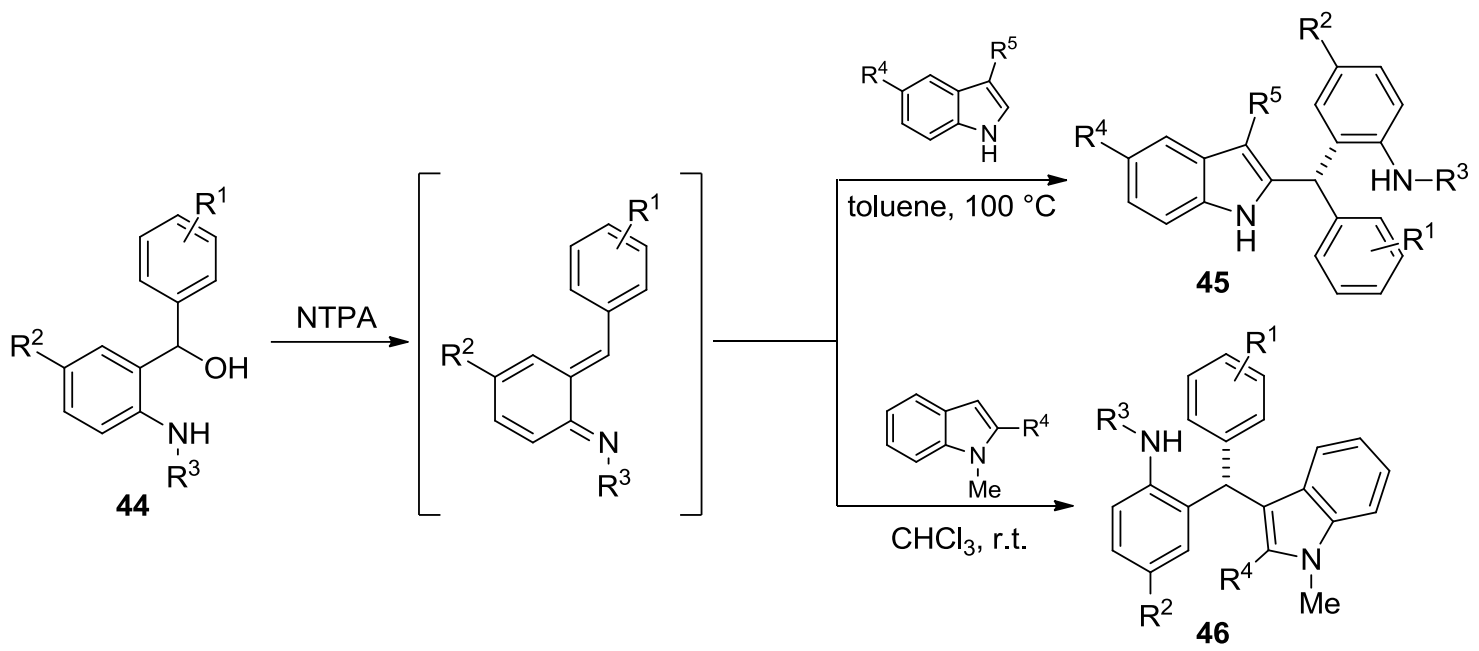

Scheme 6. Brønsted acid-catalysed reaction between aza-o-QMs and 2- or 3-substituted indoles

Two recent publications related to this topic have been reported by Deb et al. ${ }^{87,88}$. Various 2-(aminoalkyl)phenols or 1-(aminoalkyl)naphthols (47) were reacted with indoles under Brønsted acid catalysis resulting in 3-( $\alpha, \alpha$-diarylmethyl)indoles 48 . Then, through $\mathrm{C}-2$ cyclization of the indole ring using $\mathrm{I}_{2}$ as catalyst and tert-butyl hydroperoxide as oxidant, chromeno[2,3-b]indoles were isolated in $71-98 \%$ yields. In a different reaction pathway, starting from 3(aminoalkyl)indoles 49 and phenols or naphthols, 3-( $\alpha, \alpha$-diarylmethyl)indoles 48 were also formed in around $90 \%$ yields under microwave irradiation. (Scheme 7)
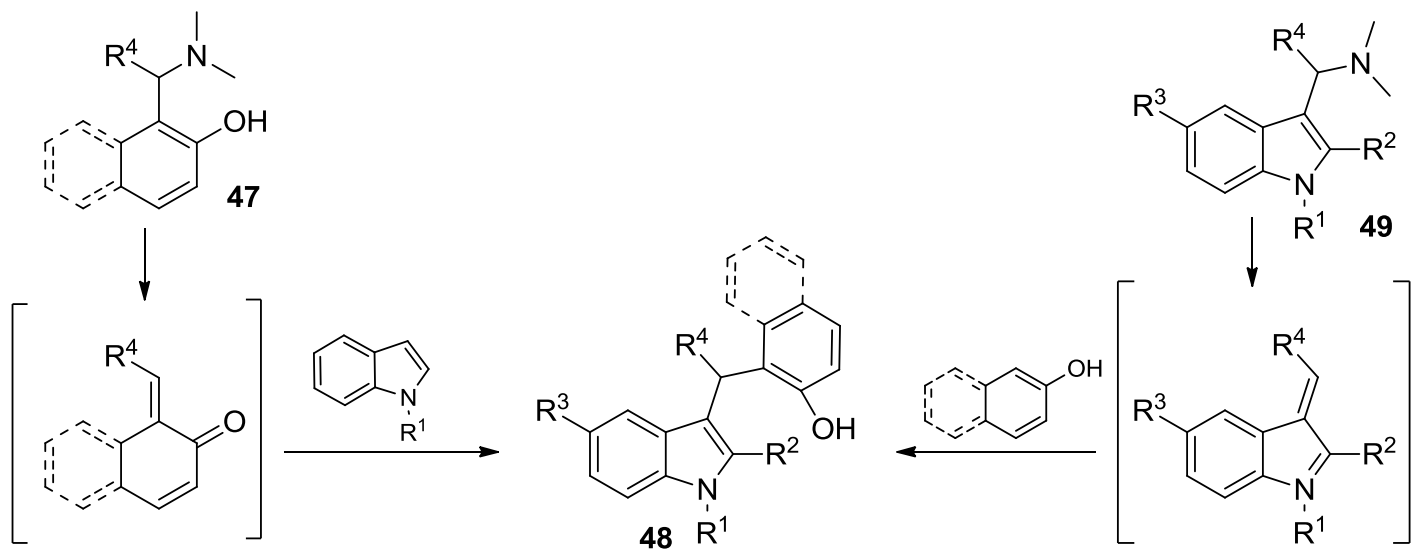

Scheme 7. Formation of 3-( $\alpha, \alpha$-diarylmethyl)indoles $\mathbf{4 8}$ in different synthetic pathways 


\subsubsection{Miscellaneous reactions}

It is also known that $o$-QMs could cross-link two biologically important molecules such as peptides, proteins or nucleic bases. Achieving the reaction under physiological conditions, it is possible to extend the syntheses to biomolecular applications.

Starting from (2-hydroxybenzyl)trimethylammonium iodide 50, Freccero et al. successfully trapped $o$-QMs formed by several $N, O$ and $S$ nucleophiles. ${ }^{89}$ They examined both thermal and photochemical generations of such intermediates. By selecting appropriate reaction conditions (various $\mathrm{pH}$ and temperatures), they were able to alkylate free amino acids, e.g. glycine (Gly), L-serine (Ser), L-cysteine (Cys), L-lysine (Lys), L-tyrosine (Tyr) and glutathione (Glu) in aqueous solutions to isolate 51. (Scheme 8)

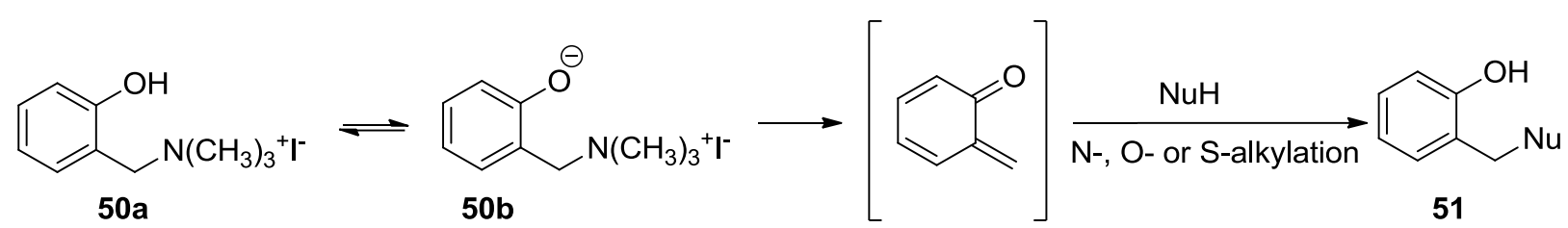

$\mathrm{NuH}=n \mathrm{PrNH}_{2}, t \mathrm{BuNH}_{2}$, aniline, piperidine, morpholine, 2-mercaptoethanol, Gly, Ser, Cys, Lys, Tyr, Glu

Scheme 8. Alkylation of $o$-QMs with $N, O$ or $S$ nucleophiles

Rokita et al. focused on generating $o$-QMs and used them as cross-linking and DNA alkylating agents. Starting from Mannich base $\mathbf{5 2}$ and transforming it by a number of synthetic steps, they were managed to elaborate a process that provides easy access to $o$-QM precursors containing a broad array of linkers $(\mathbf{5 3})$, which were used to connect with site-directing ligands ${ }^{90}$. (Scheme 9)

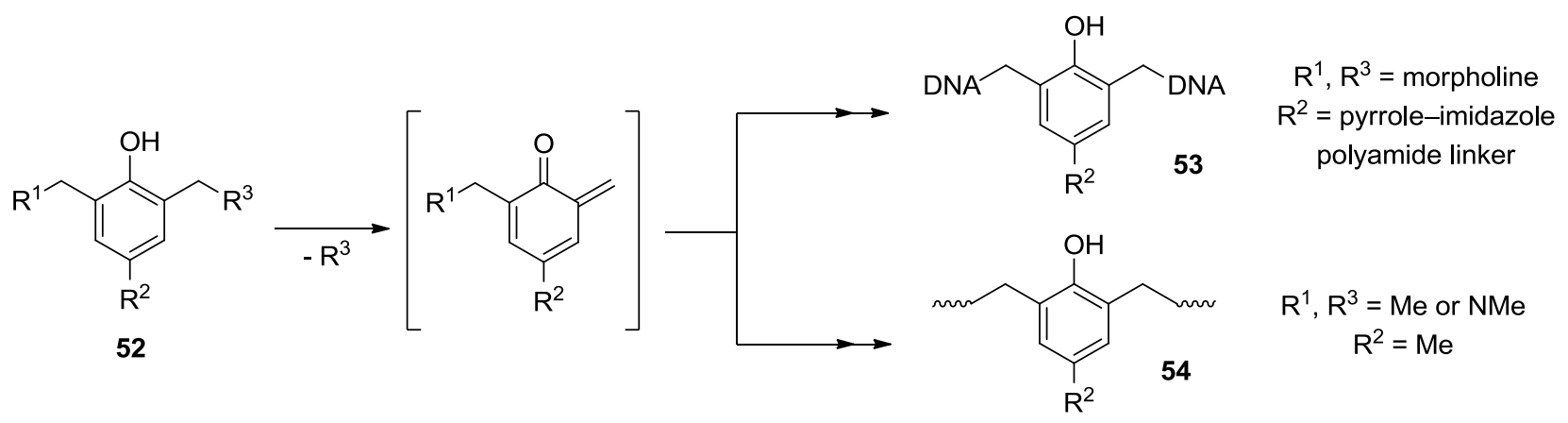

Scheme 9. Formation of DNA linkers and $o$-QM-mediated polymers 
$o$-QMs as reactive intermediates can also play the role of monomers to go through polymerization. Ishida et al. reported the ring-opening polymerization of monofunctional alkylsubstituted aromatic amine-based benzoxazines ${ }^{91}$. It was shown that the methylene bridges can be formed by $\boldsymbol{o}$-QMs, that are resulted by the cleavage of phenolic Mannich bridge structure $\mathbf{5 2}$. (Scheme 9)

\subsubsection{Biological properties}

As discussed earlier, $o$-QMs are known as short-lived, highly reactive intermediates. Therefore, their biological activity is mostly examined from the point of view of their application as DNA alkylating agents. One of the first examples was reported by Kearney et al. in 1996 about preformulation studies of the antitumor agent topotecan ${ }^{92}$. The antitumor activity of the compound could be explained by its degradation to highly active zwitterionic species via a $o$-QM intermediate. Dimmock et al. subsequently examined the cytotoxic activity of phenolic azobenzene Mannich bases ${ }^{93}$. Correlations were found between structures and activities against murine P388DI and L1210 cells as well as human T-lymphocyte cell lines and, in some cases, mutagenous properties were also shown.

Freccero et al. examined the photogeneration by laser flash photolysis and reactivity of naphthoquinone methides as well as their activity as purine-selective DNA alkylating agents ${ }^{94}$. Farrell et al. studied the mechanism of cytotoxic action of naphthoquinone-platinum(II) complexes ${ }^{95}$. Both DNA binding and Topoisomerase I inhibition studies proved that coordination and stabilization of the quinone methide structure can effect marked changes in DNA reactivity. In a recent publication, 3-(aminomethyl)naphthoquinones were investigated from the point of view of cytotoxicity, structure-activity relationship and electrochemical behaviour ${ }^{96}$. Derivatives that contain aromatic amine and salicylaldehyde or 2-pyridinecarboxaldehyde moiety were found to be the most active against HL-60 (promyelocytic leukaemia) cell line. Zhou et al. obtained phenolic Mannich bases bearing functional groups that are suitable for cross-linking DNA; therefore, their antitumor effects could also be confirmed ${ }^{97}$.

The formation of $o$-QMs and their biological properties were also illustrated by kinetic studies. Rokita et al. using laser flash photolysis showed that formation and reactivity of these intermediates strongly depend on the presence of electron-donating or electron-withdrawing functional groups of the $o$-QM precursors ${ }^{98}$. 


\section{RESULTS AND DISCUSSION}

\subsection{Synthesis of new naphthoxazines, oxazinoisoquinolines and oxazinoquinolines via $\mathbf{C 1}$ coupling of cyclic imines with electron rich aromatic compounds}

Based on papers related to the thesis, the numbering of each compounds are indicated as follows: 4,5-dihydro-3H-benz $[c]$ azepine $(\mathbf{5 5} ; I / \mathbf{5})$

\subsection{1. $\mathrm{C} 1$ coupling of 4,5-dihydro-3H-benz[c]azepine with 1- and 2-naphthol or their $\mathrm{N}$ -} containing analogues

We started our investigation with the applicability of 4,5-dihydro- $3 H$-benz $[c]$ azepine $(\mathbf{5 5}$; I/5) in C1 coupling reactions. First partially saturated cyclic amine $\mathbf{5 5}$ was synthesized in 4 steps starting from $\alpha$-tetralone according to a literature method ${ }^{99,100}$. In our first experiments, naphthols were reacted with 55 resulting in aminonaphthol derivatives $56(I / 7)$ and $57(I / \mathbf{1 1})$. (Scheme 10) The reactions were not only achieved by classical heating, but also by using microwave irradiation. It is well known that microwave heating can accelerate reactions and increase yields. Indeed, after the optimization procedure, our expectation was realized and, consequently, microwave irradiation was used in further reactions. Related data with respect to reaction conditions and yields are shown in Table 4.<smiles>[Y]=C=[Sb]</smiles><smiles>Sc1cccc2c1C=NCCC2</smiles>
55<smiles>Oc1ccc2ccccc2c1</smiles><smiles>[X]c1cccc(O)c1C1NCCCc2ccccc21</smiles>

$\mathrm{X}=\mathrm{CH}: 57$

$\mathrm{N}: 59$

Scheme 10. Synthesis of bifunctional compounds 56-59

The synthesis was then extended for the reaction of $\mathbf{5 5}$ with $N$-containing naphthol analogues 5-hydroxyisoquinoline and 6-hydroxyquinoline under microwave irradiation in 1,4-dioxane at $80{ }^{\circ} \mathrm{C}$ resulting in the formation of 58 (I/9) and 59 (I/13). Experimental results show that aminonaphthols $\mathbf{5 6}$ and $\mathbf{5 7}$ were formed in shorter reactions affording higher yields, whereas the 
formation of aminoisoquinolinol 58 and aminoquinolinol 59 required longer reaction times and yields were somewhat lower. (Table 4)

Table 4. Optimation of reaction conditions for the preparation of benzazepine-substituted compounds 56-59

\begin{tabular}{ccccc}
\hline Product & Conditions $^{\mathbf{a}}$ & Yield $^{\mathbf{a}}(\boldsymbol{\%})$ & Conditions $^{\mathbf{b}}$ & Yield $^{\mathbf{b}}(\boldsymbol{\%})$ \\
\hline $\mathbf{5 6}$ & $150 \mathrm{~min}, 80^{\circ} \mathrm{C}$ & 54 & $60 \mathrm{~min}, 80^{\circ} \mathrm{C}$ & 73 \\
$\mathbf{5 7}$ & $150 \mathrm{~min}, 80^{\circ} \mathrm{C}$ & 64 & $90 \mathrm{~min}, 80^{\circ} \mathrm{C}$ & 74 \\
$\mathbf{5 8}$ & $10 \mathrm{~h}, 80^{\circ} \mathrm{C}$ & 58 & $100 \mathrm{~min}, 80^{\circ} \mathrm{C}$ & 68 \\
$\mathbf{5 9}$ & $8 \mathrm{~h}, 80^{\circ} \mathrm{C}$ & 43 & $120 \mathrm{~min}, 80^{\circ} \mathrm{C}$ & 64 \\
\hline \multicolumn{5}{r}{ classical heating; ${ }^{\mathrm{b}}$ microwave irradiation }
\end{tabular}

3.1.2. $\mathrm{C} 1$ coupling of 6,7-dihydrothieno[3,2-c]pyridine with 1- and 2-naphthol or their $N$ containing analogues

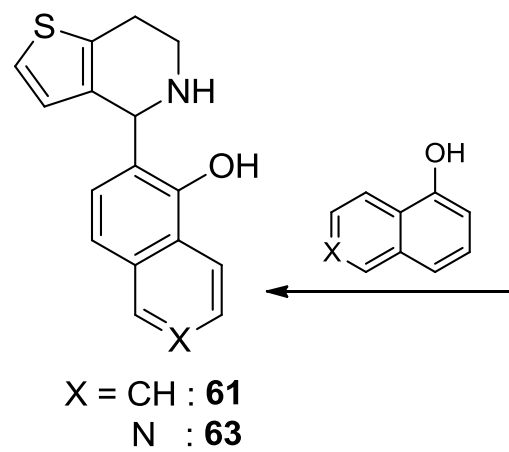

Scheme 11. Synthesis of bifunctional compounds 61-64

To extend the line of new polyheterocycles, 6,7-dihydrothieno[3,2-c]pyridine $(\mathbf{6 0} ; I / \mathbf{6})$ was then chosen as representative cyclic imine. 60 was synthesized via Bischler-Napieralski cyclization based on the method known in the literature starting from 2-thiophen-2-ylethylamine ${ }^{101}$. Partially saturated cyclic amine $\mathbf{6 0}$ was reacted with various electron-rich aromatic compounds such as 1- or 2-naphthol and analogous $N$-containing naphthol derivatives 5hydroxyisoquinoline or 6-hydroxyquinoline. The desired products 1-(1-hydroxynaphth-2-yl)thienopyridine $\quad(\mathbf{6 1}, \quad I / 8), \quad$ 1-(2-hydroxynaphth-1-yl)-thienopyridine $\quad(62, \quad I / 12)$, hydroxyisoquinolylthienopyridine $(\mathbf{6 3}, I / \mathbf{1 0})$ and hydroxyquinolyl-thienopyridine $(\mathbf{6 4}, I / \mathbf{1 4})$ formed were isolated and purified by column chromatography or by a simple crystallization followed by recrystallization. The application of microwave irradiation, again, proved to be better 
than classical heating providing the desired thienopyridine derivatives in improved yields and shorter reactions (Table 5). Comparing benzazepine-fucntionalized compounds to thienopyridinesubstituted derivatives, it is concluded that $\mathbf{6 0}$ formed the desired polyheterocycles $\mathbf{6 1}$ and 62 in higher yields than as in case of the application of 4,5-dihydro-3H-benz[c]azepine (55). As concerns the electron-rich aromatic compounds, 1- and 2-naphthol displayed higher reactivity than $\mathrm{N}$-containing derivatives 5-hydroxyisoquinoline and 6-hydroxyquinoline.

Table 5. Optimation of the reaction conditions for the preparation of thienopyridinefunctionalized compounds 61-64

\begin{tabular}{ccccc}
\hline Product & Conditions $^{\mathbf{a}}$ & Yield $^{\mathbf{a}}(\boldsymbol{\%})$ & Conditions $^{\mathbf{b}}$ & Yield $^{\mathbf{b}}(\boldsymbol{\%})$ \\
\hline $\mathbf{6 1}$ & $150 \mathrm{~min}, 85^{\circ} \mathrm{C}$ & 59 & $60 \mathrm{~min}, 85^{\circ} \mathrm{C}$ & 84 \\
$\mathbf{6 2}$ & $150 \mathrm{~min}, 80^{\circ} \mathrm{C}$ & 65 & $90 \mathrm{~min}, 80^{\circ} \mathrm{C}$ & 80 \\
$\mathbf{6 3}$ & $10 \mathrm{~h}, 80^{\circ} \mathrm{C}$ & 60 & $80 \mathrm{~min}, 80^{\circ} \mathrm{C}$ & 63 \\
$\mathbf{6 4}$ & $10 \mathrm{~h}, 80^{\circ} \mathrm{C}$ & 42 & $120 \mathrm{~min}, 80^{\circ} \mathrm{C}$ & 58 \\
\hline \multicolumn{5}{c}{ classical heating; ${ }^{\mathrm{b}}$ microwave irradiation }
\end{tabular}

\subsubsection{C1 coupling of (4aS,8aS)-4a,5,6,7,8,8a-hexahydro-2-quinoxalinone with 1- and 2- naphthol}

Next we examined the reactivity of $(4 \mathrm{a} S, 8 \mathrm{a} S)-4 \mathrm{a}, 5,6,7,8,8 \mathrm{a}-$ hexahydro-2-quinoxalinone $(\mathbf{6 5} ; \mathrm{III} / \mathbf{1})$ as enantiomeric cyclic imine with different electron-rich aromatic compounds. For the preparation of $\mathbf{6 5}$ the method known in the literature ${ }^{102}$ was optimized by using the following microwave conditions: $1 S, 2 S$-diaminocyclohexane and ethyl glyoxylate were mixed in toluene and reacted for $20 \mathrm{~min}$ at $80{ }^{\circ} \mathrm{C}$ resulting in nonracemic hexahydroquinoxalinone in good yield.

With quinoxalinone derivative $\mathbf{6 5}$ in hand, $\mathrm{C} 1$ coupling reactions with 1- or 2-naphthol were carried out at $80^{\circ} \mathrm{C}$ under neat conditions using conventional heating. Full conversions are reached in relatively short reaction times (20 and $30 \mathrm{~min}$ ); therefore, in this case, the application of microwave irradiation was unnecessary.

Since a new chiral centre is generated during these reactions, the formation of a pair of diastereomers can take place in each case. According to our observations based on TLC and crude product NMR spectra, the reaction of 2-naphthol proved to be diastereoselective and 66a (III/18a) was isolated as a single product. The reaction between 1-naphthol and $\mathbf{6 5}$, in turn, resulted in the formation of three novel compounds: the two possible diastereomers $(67 \mathbf{a} ; I I I / 19 \mathbf{a}$ and $67 \mathbf{b} ; I I I / 19 b)$ and a bis-product 
$(67 \mathrm{c} ; I I I / 19 \mathrm{c})$. The formation of compound $67 \mathrm{c}$ can be explained by the directing effect of the hydroxy group allowing substitution taking place in position 4 as well (Scheme 12).<smiles>Cc1ccc2cc(O)ccc2c1</smiles>

65<smiles>O=C1N[C@H]2CCCC[C@H]2N[C@@H]1c1c(O)ccc2ccccc12</smiles>

$66 a, 52 \%$<smiles>O=C1C=N[C@H]2CCCC[C@H]2N1</smiles>

65

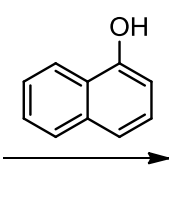

W $67 a, 28 \%$<smiles>O=C1N[C@H]2CCCC[C@H]2NC1c1ccc2ccccc2c1O</smiles>

$+$<smiles>O=C1N[C@H]2CCCC[C@H]2N[C@@H]1c1ccc2ccccc2c1O</smiles>

$67 b, 21 \%$

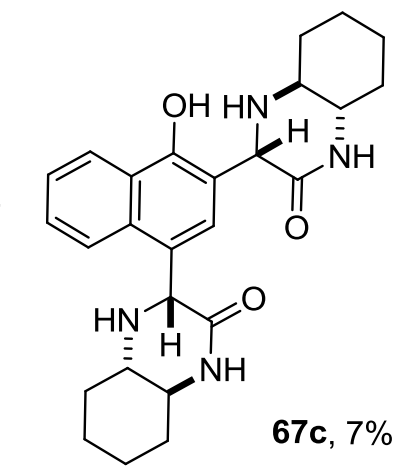

Scheme 12. Synthesis of bifunctional compounds 66-67

By repeating the reactions at various temperatures, the kinetic effects on the diastereomeric ratios were also tested. Conditions were chosen as follows: conventional heating under neat conditions at room temperature, 60,80 or $100^{\circ} \mathrm{C}$. The diastereomeric ratios were compared by evaluating crude product NMR spectra based on the integrate values of the $\mathrm{CH}$ singlets for each compound. In the case of 2naphthol, the concentration of the minor diastereomer was under the detection limit. In contrast, when the substrate was 1-naphthol, a change in the ratio of the formed compounds was observed. Increasing the temperature gave increasing $67 \mathbf{b}$ to $67 \mathbf{a}$ ratios, while the amount of bis-product $67 \mathbf{c}$ was around $10 \%$ (Table 6).

Table 6. Effect of temperature on product composition for isomeric compounds 67

\begin{tabular}{ccc}
\hline Entry & Temperature & $\mathbf{6 7 a}: \mathbf{6 7 b}: \mathbf{6 7 c}$ \\
\hline 1 & $25{ }^{\circ} \mathrm{C}$ & $40: 48: 12$ \\
2 & $60{ }^{\circ} \mathrm{C}$ & $38: 54: 8$ \\
3 & $80{ }^{\circ} \mathrm{C}$ & $27: 66: 7$ \\
4 & $100{ }^{\circ} \mathrm{C}$ & $24: 68: 8$ \\
\hline
\end{tabular}


3.1.4. Ring-closure reactions of secondary aminonaphthols, aminoquinolinols and aminoisoquinolinols and conformational analysis of the new naphth[1,3]oxazino-heterocycles

After having each benzazepine-, thienopyridine- and quinoxalinone-fused bifunctional compound in hand, their ring-closure reactions were performed to isolate novel naphth[1,3]oxazino[4,3-a] heterocycles. Syntheses were performed at room temperature in dichloromethane using a 35\% solution of formaldehyde as cyclizing agent.

After 20-30 minutes reaction times, full conversions were reached and the desired naphthoxazine, oxazinoisoquinoline and oxazinoquinoline products $(\mathbf{6 8} ; I / \mathbf{1 5}, \mathbf{6 9} ; I / \mathbf{1 9}, \mathbf{7 0} ; I / \mathbf{1 7}$, 71; I/21, 72; I/16, 73;I/20, 74; I/18, 75;I/22, 76a; III/21a, 76b;III/21b, 77a; $I I I / 20 a)$ were isolated in excellent yields by simple crystallization in $n$-hexane. (Table 7) Purification by recrystallization in $n$-hexane delivered pure products. In the case of bis-product $67 \mathbf{c}$, the addition of formaline did not lead to the formation of the desired naphthoxazino-quinoxalinone derivative; rather, the decomposition of initial compound $67 \mathbf{c}$ occurred.

Table 7. Ring-closure reactions of benzazepine-, thienopyridine- and quinoxalinone-fused heterocycles (56-59, 61-64, 66a, 67a-b)

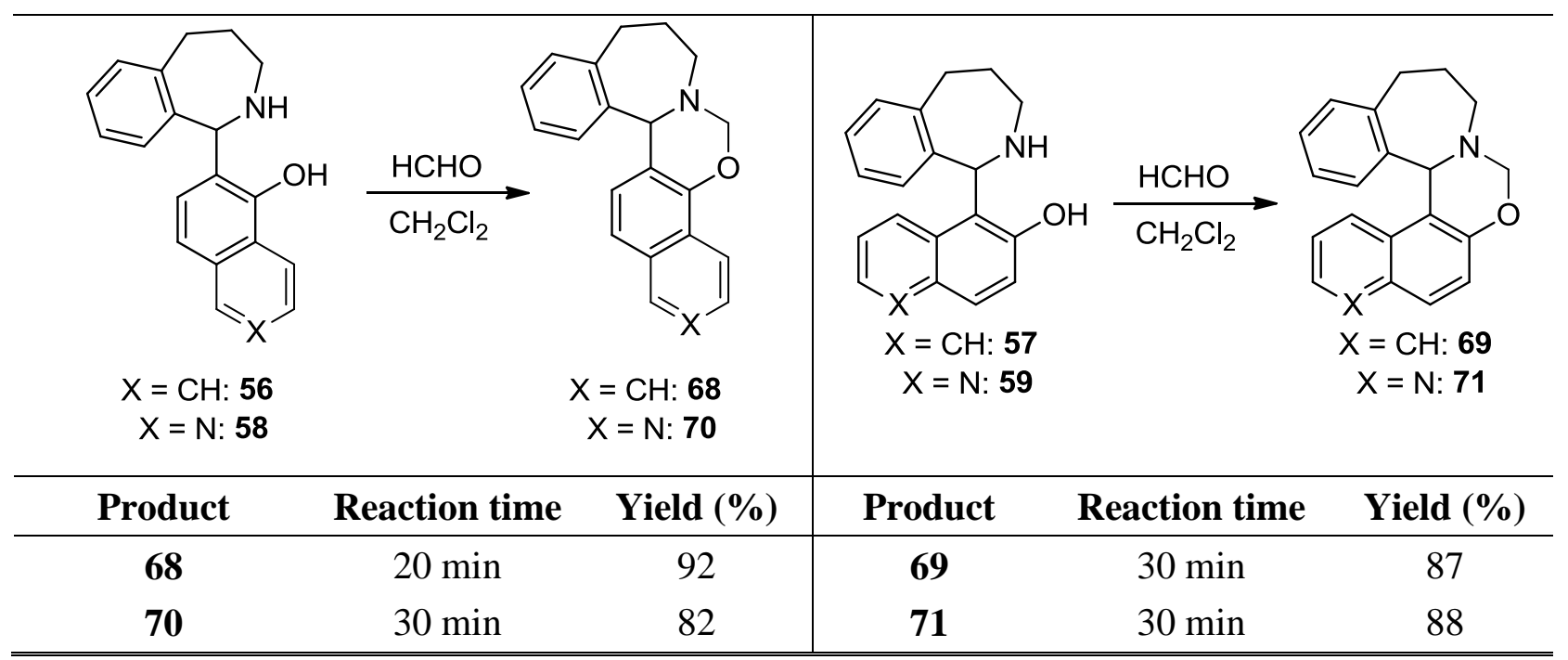




(n)

Conformational analysis of the target heterocycles was performed by NMR spectroscopy as well as theoretical calculations at the DFT level of theory. ${ }^{103-105}$ Representative examples are discussed below.

In the case of $\mathbf{7 2}$ and $\mathbf{7 3}$, all configurations of the stereogenic centres were studied at the DFT level of theory with respect to the preferred conformers or conformational equilibria. One chiral central centre at $\mathrm{C}(14 \mathrm{~b})$ is present in both $\mathbf{7 2}$ and $\mathbf{7 3}$, and the frozen $\mathrm{sp}^{3}$-nitrogen $\mathrm{N}(9)$ can have either $R$ or $S$ configuration.

For 72 and 73, the most stable configurations of $S(14 \mathrm{~b}), R(\mathrm{~N})$ and $R(14 \mathrm{~b}), S(\mathrm{~N})$, respectively, were obtained. Energy differences to the energetically next coming isomers are 2.82 and $3.68 \mathrm{kcal}$ $\mathrm{mol}^{-1}$, respectively. These values are too discriminating for any significant population of another, energetically next coming conformer. The isomers in the most stable conformation, thus obtained, are the basis for structure elucidation employing NMR spectroscopy. As shown in Fig. 1, oxazine rings prefer a twisted chair conformation. In addition, the spatial NOE information is in complete agreement with the theoretical structures. 

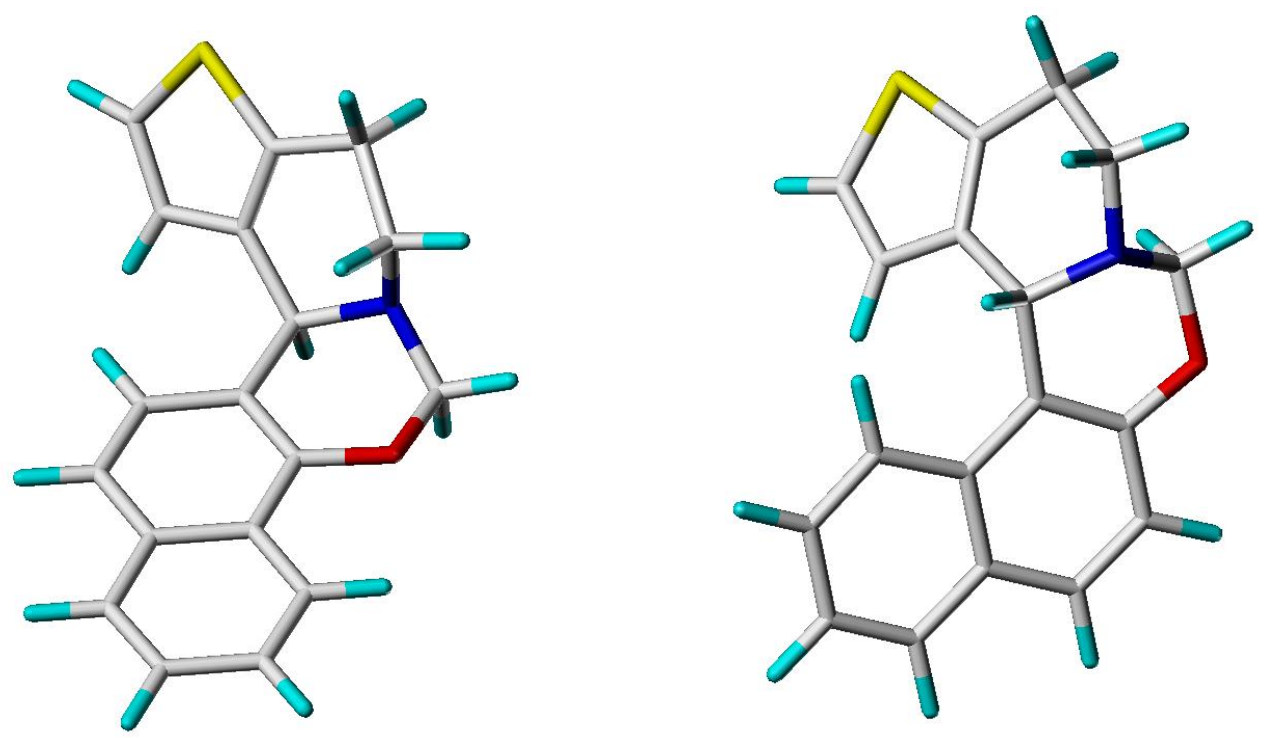

Fig. 1. Stereochemistry of $72[S(14 \mathrm{~b}), R(\mathrm{~N})]$ and $73[R(14 \mathrm{~b}), S(\mathrm{~N})]$ obtained by DFT calculations and supported by the corresponding spatial NOE information.

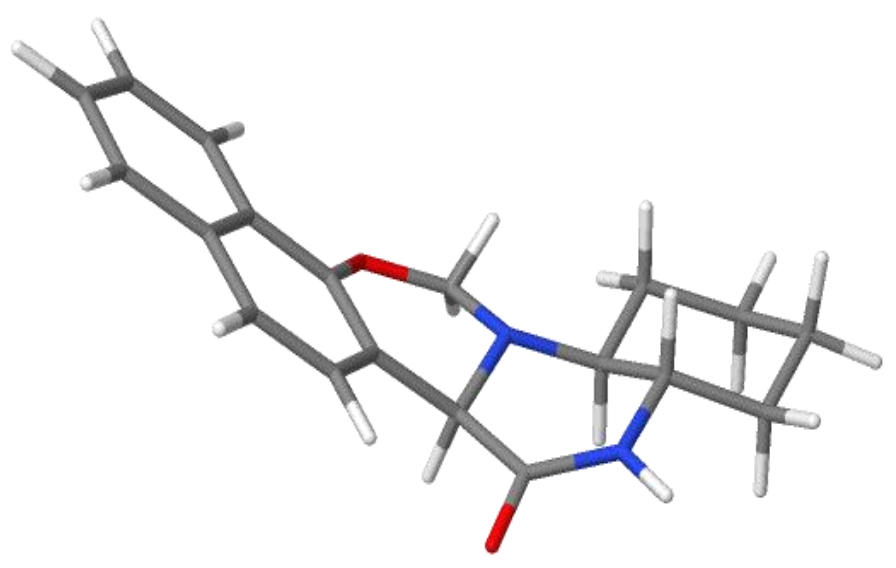

76a

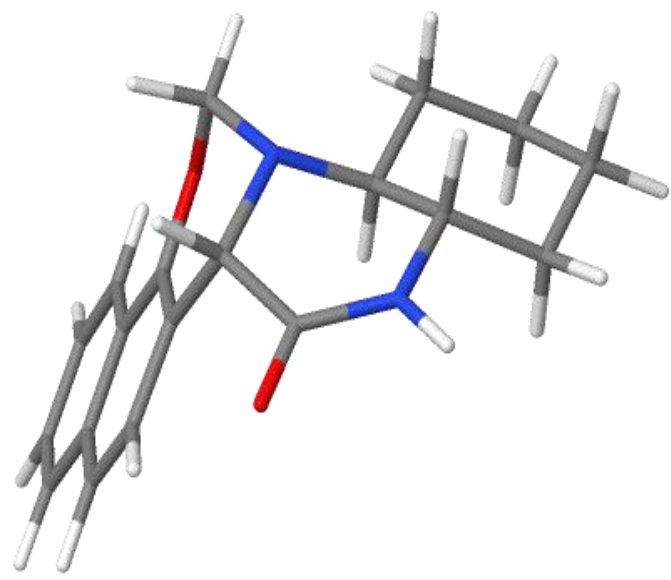

$76 b$

Fig. 2. Stereochemistry of compounds $\mathbf{7 6 a}$ and $\mathbf{7 6 b}$

In the case of compounds $\mathbf{7 6 a}$ and $\mathbf{7 6}$, NMR studies (the NOE interactions between $\mathrm{H}-12$ and the cyclic ring protons) clarified that the junction of the heterocyclic rings is trans in 76a and cis in 76b. Accordingly, the configuration of the newly-formed stereogenic centres could be determined. As shown in Fig. 2, further modelling and DFT calculations proved the stereochemistry indicating that the newly-generated oxazine ring prefers a half-boat conformation in both cases. 


\section{2. [4+2] Cycloaddition reactions of cyclic imines and o-QMs formed by various aminonaphthols}

The plausible mechanism of this reaction is based on a report published by our research group in 2011.23 According to this observation, the initial aminonaphthol derivative first undergoes a retro-Michael reaction by the loss of ammonia leading to the formation of an $o$-QM structure. This intermediate then reacts with 3,4-dihydroisoquinoline as cyclic imine in a [4+2] cycloaddition to form the desired naphthoxazino-isoquinoline derivatives.

\subsubsection{Reactions of 4,5-dihydro-3H-benz[c]azepine and various aminonaphthols}

To synthesize novel napth[1,3] oxazino[2,3-a]benzazepine derivatives, partially saturated cyclic amine 55 (II/1) was first reacted with 1-aminomethyl-2-naphthol (78a; II/2a). The synthesis was performed in 1,4-dioxane under microwave irradiation at $80{ }^{\circ} \mathrm{C}$. Crystallization of the product in methanol followed by recrystallization in methanol gave 79a (II/3a) in a good yield. (Table 8)

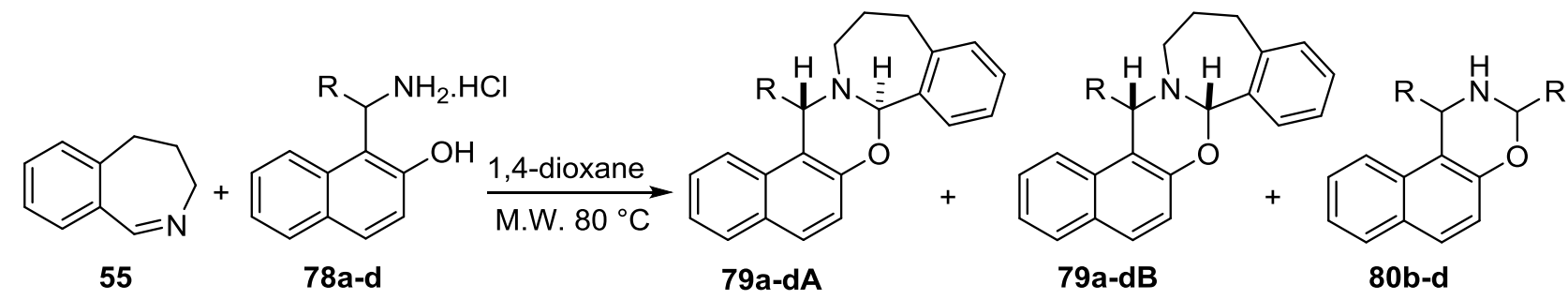

$\mathrm{R}: \mathrm{H}(\mathbf{a}), \mathrm{Ph}(\mathbf{b})$, 1-Nph (c), 2-Nph (d)

Scheme 13. Reactions between cyclic imine 55 and primary aminonaphthols 78a-d

The reaction of primary aminonaphthol $\mathbf{7 8 b}(I I / \mathbf{2 b})$ and $\mathbf{5 5}$, however, resulted in the formation of an undesired compound $(\mathbf{8 0 b} ; I I / \mathbf{4 b})$. It was presumed to be a side product reported in one of the publications of our research group ${ }^{106}$. Formation of $\mathbf{8 0 b}$ can be accounted for by the reaction of $\mathbf{7 8 b}$ and benzaldehyde formed as a result of the decomposition of $\mathbf{7 8 b}$. trans-80b and its acyclic imine form were detected by TLC and assigned by NMR spectroscopy using the characteristic H-3 chemical shifts at $5.64 \mathrm{ppm}$ and $8.77 \mathrm{ppm}$. Purification by column chromatography gave new pentacycle 79b identified as trans diastereomer 79bA (II/3bA, Scheme 13) based on NOE measurements. 
Note that the formation of two diastereomers is possible in all cases. Therefore, the diastereomeric ratios were examined in the crude reaction mixture.

Table 8. Reaction conditions for the preparation of naphthoxazino-benzazepines (79a-d)

\begin{tabular}{|c|c|c|c|c|c|c|}
\hline Aminonaphthol & $\begin{array}{c}\text { Reaction } \\
\text { time }(\min )^{\mathrm{a}}\end{array}$ & \multicolumn{3}{|c|}{ Product(s) } & $\begin{array}{c}\text { Conversion }^{b} \\
(\%)\end{array}$ & $\begin{array}{c}\text { Yield }^{\mathrm{c}} \\
(\%)\end{array}$ \\
\hline $78 a$ & 30 & \multicolumn{3}{|c|}{$79 a$} & 91 & 77 \\
\hline $78 b$ & 80 & $\begin{array}{l}\text { 79bA } \\
(48 \%)\end{array}$ & $\begin{array}{l}79 b B \\
(0 \%)\end{array}$ & $\begin{array}{c}\mathbf{8 0 b} \\
(52 \%)\end{array}$ & 92 & 37 \\
\hline 78c & 80 & $\begin{array}{l}\text { 79cA } \\
(44 \%)\end{array}$ & $\begin{array}{l}79 \mathrm{cB} \\
(0 \%)\end{array}$ & $\begin{array}{c}\mathbf{8 0 c} \\
(56 \%)\end{array}$ & 91 & 34 \\
\hline 78d & 40 & $\begin{array}{l}\text { 79dA } \\
(45 \%)\end{array}$ & $\begin{array}{l}\text { 79dB } \\
(0 \%)\end{array}$ & $\begin{array}{c}\text { 80d } \\
(55 \%)\end{array}$ & 88 & $-d$ \\
\hline
\end{tabular}

${ }^{a}$ syntheses were achieved at $80^{\circ} \mathrm{C}$ using microwave irradiation

${ }^{b}$ conversion, calculated from the ${ }^{1} \mathrm{HNMR}$ spectra of the crude reaction mixtures

${ }^{\mathrm{c}}$ isolated yields, obtained for the major (A) products

d $79 d \mathbf{A}$ and the by-product $(\mathbf{8 0 d})$ could not be separated

Syntheses were then extended by the application of aminonaphthols $\mathbf{7 8 c}(I I / 2 c)$ and $\mathbf{7 8 d}$ (II/2d) using the same conditions mentioned above. According to TLC and crude product NMR spectra, the presence of the desired pentacycles $79 \mathbf{c}(I I / 3 \mathbf{c})$ and $79 \mathbf{d}(I I / 3 \mathbf{d})$ was detected along with undesired naphthoxazine side products 80c (II/4c) and 80d (II/4d), respectively. Purifying each compounds by column cromatography in different composition of $n$-hexane : ethyl-acetate, the separation proved to be successful in the case of 79c and 80c, but failed for the mixture of 79d and 80d. Since further purification by different techniques (e.g. recrystallization) were found to be ineffecient to separate the desired naphthoxazine, the development of a new synthetic strategy was needed to isolate $\mathbf{7 9 d}$ in pure form.

While the formation of the undesired naphthoxazine side product can only occur when starting from primary aminonaphthols, the preparation of the missing naphthoxazino-benzazepine derivative 79d was planned by using tertiary aminonaphthol 81 (II/14) as the starting material. The synthesis of $\mathbf{8 1}$ was achieved by stirring a mixture of 2-naphthol, 2-naphthaldehyde and $N$ benzylmethylamine at $80{ }^{\circ} \mathrm{C}$ for 10 hours. The desired initial compound was then isolated by a simple crystallization in methanol, followed by recrystallization in methanol. Pure $\mathbf{8 1}$ was then reacted with cyclic imine $\mathbf{5 5}$ at $80{ }^{\circ} \mathrm{C}$ under microwave irradiation affording $\mathbf{7 9 d A}$ diastereoselectively, without any naphthoxazine side products. 79dA then could easily be isolated in a pure form by crystallization in methanol followed by recrystallization in methanol. (Scheme 14) 


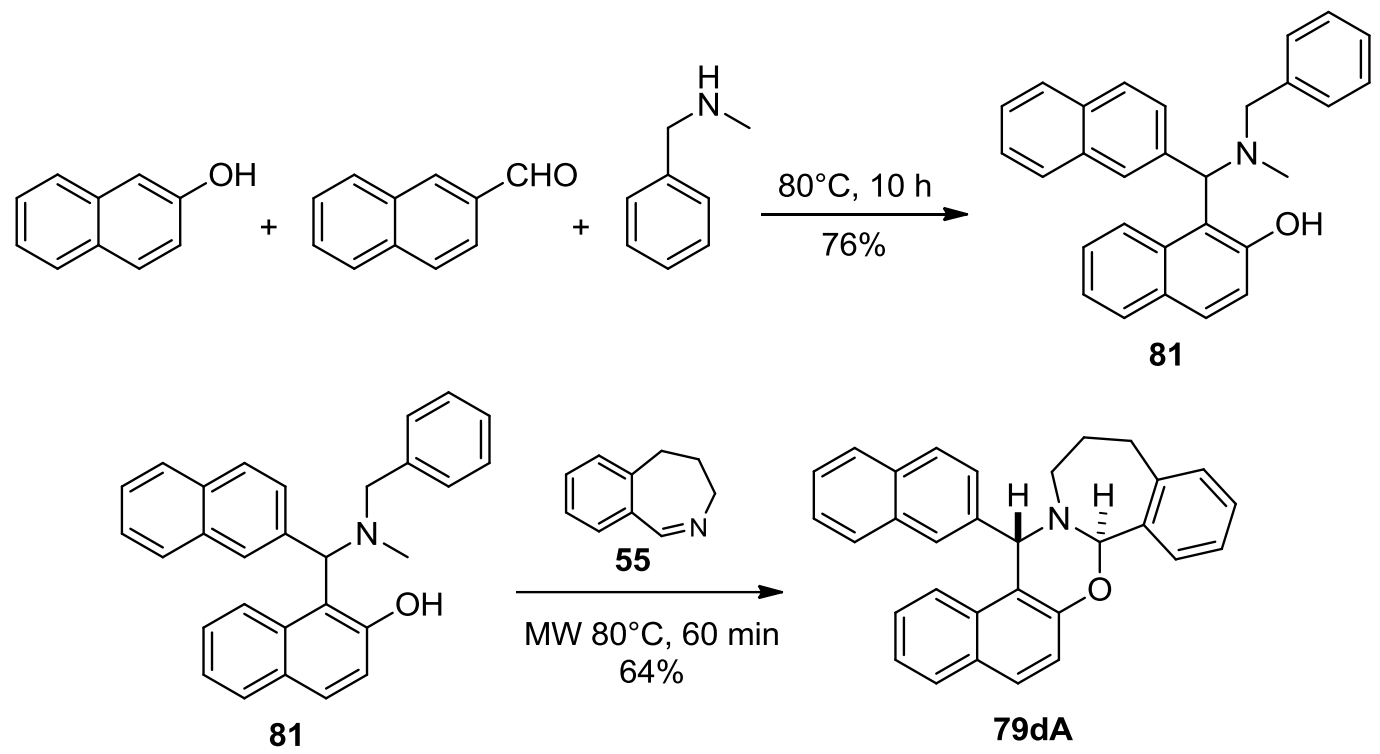

Scheme 14. Synthesis of 79d starting from tertiary aminonaphthol

To examine the possibility of the extension of the reaction, 2-aminobenzyl-1-naphthols (82b-d; II/5b-d) were then applied in annulation reactions. Syntheses were carried out under microwave irradiation with almost full conversions in short reaction times. Related results and

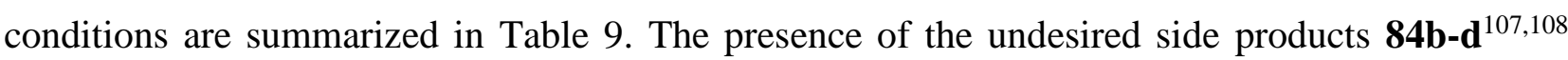
(II/7b-d) were also detected. However, column cromatography in $n$-hexane : ethyl-acetate allowed

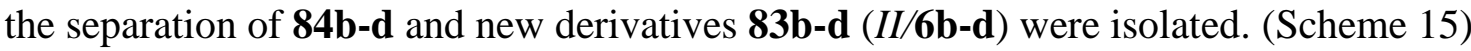<smiles>[R]C(N)c1ccc2ccccc2c1O</smiles>

$82 b-d$ $\underset{\text { M.W. }}{\stackrel{\text { M. } 80^{\circ} \mathrm{C}}{\longrightarrow}}$<smiles>[R]C1([R])c2ccc3ccccc3c2OC2c3ccccc3CCCN21</smiles>

83b-dA<smiles>[R]C1CC2(NCCCc3ccccc32)Oc2c1ccc1ccccc21</smiles>

$83 b-d B$<smiles>[R]C1NC([R])c2ccc3ccccc3c2O1</smiles>

84b-d

$\mathrm{R}: \mathrm{H}(\mathbf{a}), \mathrm{Ph}(\mathbf{b}), 1-\mathrm{Nph}(\mathbf{c})$, 2-Nph (d)

Scheme 15. Reactions between cyclic imine 55 and primary aminonaphthols 82b-d

The formation of minor diastereomers $\mathbf{8 3 b B}$ and $\mathbf{8 3 d B}$, respectively, could only be detected when the reaction was performed with $\mathbf{8 2 b}$ or $\mathbf{8 2 d}$ as aminonaphthol starting materials (Table 9). It can be concluded that the diastereoselectivity of the reaction depends on both the steric effect of the aromatic ring at position 14 or 16 and the position of annulation of the naphthalene ring. 
Table 9. Reaction conditions for the preparation of naphthoxazino-benzazepines (83b-d)

\begin{tabular}{|c|c|c|c|c|c|c|c|}
\hline Aminonaphthol & $\begin{array}{l}\text { Reaction } \\
\text { time }(\min )^{\mathrm{a}}\end{array}$ & \multicolumn{3}{|c|}{ Product(s) } & d.r. ${ }^{b}$ & $\begin{array}{l}\text { Conversion }^{\mathrm{d}} \\
(\%)\end{array}$ & $\begin{array}{l}\text { Yield }^{\mathrm{e}} \\
(\%)\end{array}$ \\
\hline $82 b$ & 40 & $\begin{array}{l}\text { 83bA } \\
(44 \%)\end{array}$ & $\begin{array}{l}\mathbf{8 3 b B} \\
(7 \%)\end{array}$ & $\begin{array}{c}\mathbf{8 4 b} \\
(49 \%)\end{array}$ & $1: 0.16$ & 93 & $-f$ \\
\hline $82 c$ & 20 & $\begin{array}{c}\mathbf{8 3 c A} \\
(48 \%)\end{array}$ & $\begin{array}{l}\mathbf{8 3 c B} \\
(0 \%)\end{array}$ & $\begin{array}{c}\mathbf{8 4 c} \\
(52 \%)\end{array}$ & $-c$ & 88 & 32 \\
\hline 82d & 40 & $\begin{array}{l}\mathbf{8 3 d A} \\
(39 \%)\end{array}$ & $\begin{array}{l}\mathbf{8 3 d B} \\
(10 \%)\end{array}$ & $\begin{array}{c}\mathbf{8 4 d} \\
(51 \%)\end{array}$ & $1: 0.25$ & 90 & $-f$ \\
\hline
\end{tabular}

${ }^{\text {a }}$ syntheses were achieved at $80{ }^{\circ} \mathrm{C}$ using microwave irradiation

${ }^{\mathrm{b}}$ diastereomeric ratio (trans:cis), determined from the ${ }^{1} \mathrm{HNMR}$ spectra of the crude reaction mixtures

${ }^{c}$ the minor distereomer could not be detected

${ }^{d}$ conversion, calculated from the ${ }^{1}$ HNMR spectra of the crude reaction mixtures

${ }^{\mathrm{e}}$ isolated yields, obtained for the major (A) products

${ }^{\mathrm{f}}$ the diastereomers $(\mathbf{8 3 d} \mathbf{d}$ and $\mathbf{8 3 d B})$ could not be separated

3.2.2. Reactions of 6,7-dihydrothieno[3,2-c]pyridine and various aminonaphthols<smiles>[R]C1NC([R])C([R])Oc2ccc3ccccc3c21</smiles>

Scheme 16. Reactions of cyclic imine 60 and substituted aminonaphthols (78a-d, 82b-d)

Next, 6,7-dihydrothieno[3,2-c]pyridine $(\mathbf{6 0}, I I / 8)$ was selected as a representative cyclic imine. (Scheme 16) In the first experiments, the desired unsubstituted naphthoxazine 85a (II/9a) was obtained in good (74\%) yield through the reaction of $\mathbf{6 0}$ and 78a (Table 10). 
Table 10. Reaction conditions for the preparation of naphthoxazino-thienopyridines (85a-d, 86b-d)

\begin{tabular}{|c|c|c|c|c|c|c|c|}
\hline Aminonaphthol & $\begin{array}{l}\text { Reaction } \\
\text { time }(\min )^{\mathrm{a}}\end{array}$ & & Product(s & & d.r. ${ }^{b}$ & $\begin{array}{c}\text { Conversion }^{\mathrm{d}} \\
(\%)\end{array}$ & $\begin{array}{c}\text { Yield }^{\mathrm{e}} \\
(\%)\end{array}$ \\
\hline 78a & 20 & & $85 a A$ & & - & 92 & 74 \\
\hline $78 b$ & 60 & $\begin{array}{l}\mathbf{8 5 b A} \\
(42 \%)\end{array}$ & $\begin{array}{l}\mathbf{8 5 b B} \\
(0 \%)\end{array}$ & $\begin{array}{c}\mathbf{8 0 b} \\
(58 \%)\end{array}$ & $-{ }^{c}$ & 93 & 38 \\
\hline $78 \mathrm{c}$ & 40 & $\begin{array}{c}\mathbf{8 5 c A} \\
(44 \%)\end{array}$ & $\begin{array}{l}\mathbf{8 5 c B} \\
(0 \%)\end{array}$ & $\begin{array}{c}\mathbf{8 0 c} \\
(56 \%)\end{array}$ & $--^{c}$ & 90 & $-f$ \\
\hline 78d & 40 & $\begin{array}{l}\mathbf{8 5 d A} \\
(46 \%)\end{array}$ & $\begin{array}{c}\mathbf{8 5 d B} \\
(0 \%)\end{array}$ & $\begin{array}{c}\text { 80d } \\
(54 \%)\end{array}$ & $-c$ & 91 & $-f$ \\
\hline $82 b$ & 20 & $\begin{array}{l}\mathbf{8 6 b A} \\
(34 \%)\end{array}$ & $\begin{array}{c}\mathbf{8 6 b B} \\
(10 \%)\end{array}$ & $\begin{array}{c}\mathbf{8 4 b} \\
(56 \%)\end{array}$ & $1: 0.30$ & 88 & $-g$ \\
\hline $82 c$ & 20 & $\begin{array}{c}\text { 86cA } \\
(49 \%)\end{array}$ & $\begin{array}{l}\mathbf{8 6 c B} \\
(0 \%)\end{array}$ & $\begin{array}{c}\mathbf{8 4 c} \\
(51 \%)\end{array}$ & $-c$ & 92 & 34 \\
\hline $82 d$ & 20 & $\begin{array}{l}\mathbf{8 6 d A} \\
(36 \%)\end{array}$ & $\begin{array}{l}\mathbf{8 6 d B} \\
(12 \%)\end{array}$ & $\begin{array}{c}\mathbf{8 4 d} \\
(52 \%)\end{array}$ & $1: 0.33$ & 89 & $-g$ \\
\hline
\end{tabular}

${ }^{\mathrm{a}}$ syntheses were achieved at $80^{\circ} \mathrm{C}$ using microwave irradiation

${ }^{\mathrm{b}}$ diastereomeric ratio (trans: $\mathrm{cis}$ ), calculated from the ${ }^{1} \mathrm{HNMR}$ spectra of the crude reaction mixtures

${ }^{\mathrm{c}}$ the minor distereomer could not be detected

${ }^{\mathrm{d}}$ conversion, calculated from the ${ }^{1} \mathrm{HNMR}$ spectra of the crude reaction mixtures

${ }^{\mathrm{e}}$ isolated yields, obtained for the major $(\mathbf{A})$ products

${ }^{f}$ the desired $(\mathbf{8 5 c A}$ or $85 \mathrm{dA})$ and the by-products $(\mathbf{8 0 c}$ or $80 \mathrm{~d})$ could not be separated

$\mathrm{g}$ the diastereomers $(\mathbf{8 6 b \mathrm { b }}$ and $\mathbf{8 6 \mathrm { bB }}$ or $\mathbf{8 6 \mathrm { dA }}$ and $\mathbf{8 6 \mathrm { dB }})$ could not be separated

Then the reaction was extended by the application of 1-aminoaryl-2-naphthols (78b-d) or 2-aminoaryl-1-naphthols (82b-d, Scheme 16). The results of the separation process of pentacycles 85b-d (II/9b-d) or 86b-d (II/10b-d) from naphthoxazines 80b-d or 84b-d depended on the structure of the initial compound. With the exception of 85c and 85d, column chromatography proved to be successful to provide the desired pentacycles 85b, 86b-d (Table 10). Because of the difficulty with $\mathbf{8 5 c}$ and $\mathbf{8 5 d}$, an alternative synthetic pathway was needed.

On the basis of the observation that only primary aminonaphthols can give naphthoxazine side products, a systematic study was started to compare the reactivity and applicability of aminonaphthols with different degrees of $N$-susbtitution. The synthesis of $\mathbf{8 5 b A}$ was chosen as model reaction with $\mathbf{7 8 b}$ as primary, $\mathbf{8 7}^{109}$ as secondary and $\mathbf{8 8}^{110}$ as tertiary aminonaphthol derivative. (Scheme 17) 
<smiles>[R]N([R])C(c1ccccc1)c1c(O)ccc2ccccc12</smiles>

$\mathrm{R}^{1}=\mathrm{H} ; \mathrm{R}^{2}=\mathrm{H}: \mathbf{7 8 b}$

$\mathrm{R}^{1}=\mathrm{H} ; \mathrm{R}^{2}=-\mathrm{CH}_{2}-\mathrm{Ph}: 87$

$R^{1}=\mathrm{Me} ; \mathrm{R}^{2}=-\mathrm{CH}_{2}-\mathrm{Ph}: \mathbf{8 8}$<smiles>C1=NCCc2sccc21</smiles><smiles>[Mg][Mg][Mg][Mg]</smiles>

60<smiles></smiles>

$78 \mathrm{~b}$

$87 \stackrel{i i}{\longrightarrow} 85 \mathrm{bA}$

$88 \stackrel{i i i}{\longrightarrow} 85 \mathrm{bA}$

Scheme 17. Synthesis of $\mathbf{8 5 b \mathbf { b }}$ starting from different aminonaphthols

Although the highest conversion was found in the reaction of $\mathbf{6 0}$ and primary aminonaphthol $\mathbf{7 8 b}$, the undesired side product $\mathbf{8 0 b}$ formed in a yield of around $55 \%$. Of secondary and tertiary aminonaphthols $(\mathbf{8 7}$ and $\mathbf{8 8})$, the transformation of $\mathbf{8 8}$ proved to be better. As shown in Figure 3, a conversion of $70 \%$ was reached in 60 min in reaction $i i i$, while $i i$ gave a conversion only around 60\% after a prolonged reaction (200 min). (Figure 3)

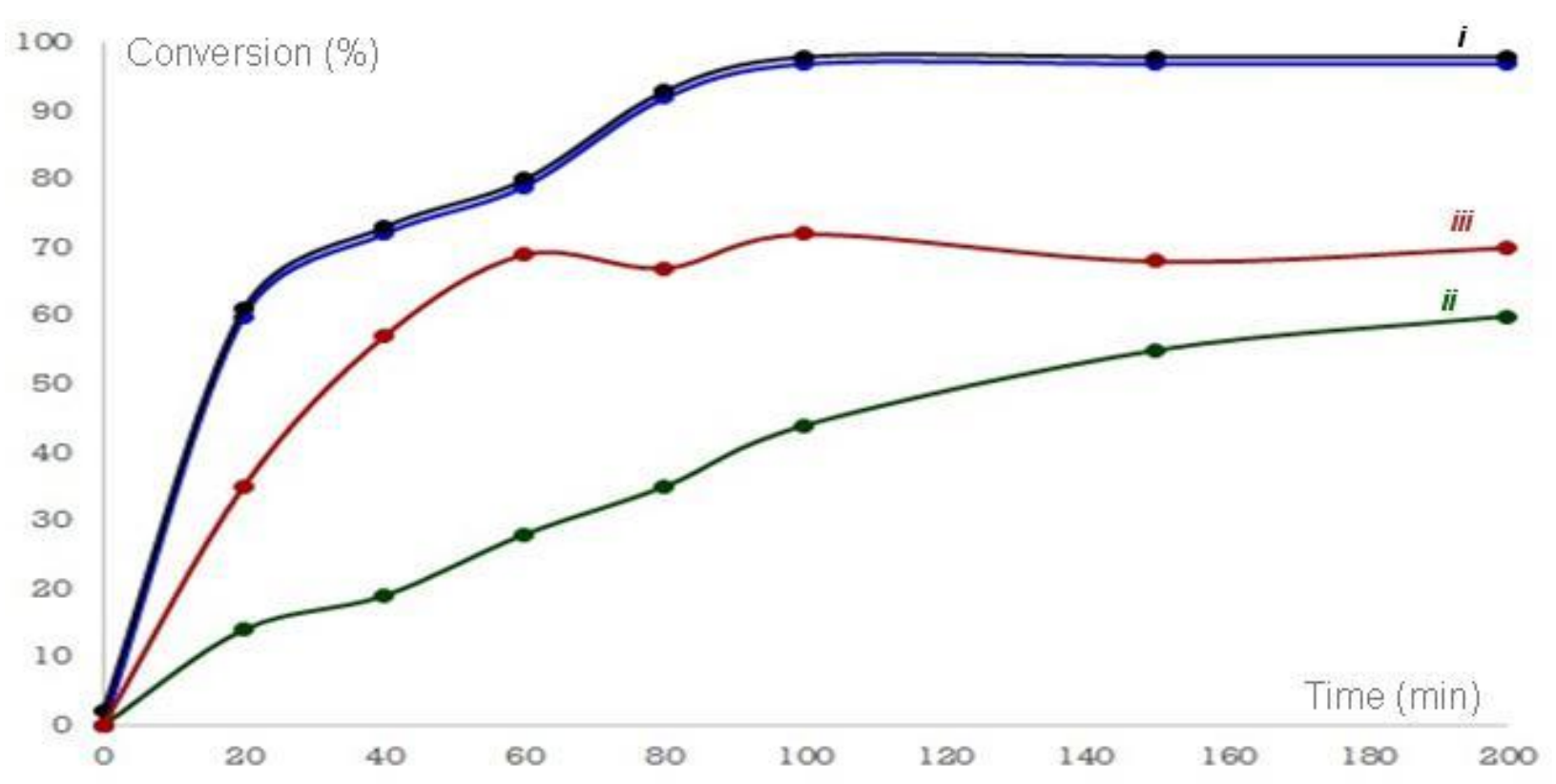

Figure 3. Comparison of aminonaphthols $\mathbf{7 8 b}($ i), 87 (ii) and 88 (iii) in the syntheses of $\mathbf{8 5 b} \mathbf{b}$

According to these observations, the selection of tertiary aminonaphthols as starting compounds and an optimal reaction time of $60 \mathrm{~min}$ appeared to be satisfactory. Therefore, the synthesis of missing derivatives $85 \mathrm{c}$ and $\mathbf{8 5 d}$ was planned by reacting 60 with tertiary aminonaphthols $(\mathbf{8 1}$ and $\mathbf{8 9} ; I / \mathbf{1 3}) .89$ was synthesized under neat conditions at $80{ }^{\circ} \mathrm{C}$ by reacting 2-naphthol, 1-naphthaldehyde and morpholine for 7 hours. 
To achieve the naphthoxazine transformations, 60 was reacted with $\mathbf{8 1}$ or $\mathbf{8 9}$ in 1,4-dioxane under microwave irradiation. The desired products $\mathbf{8 5 c}$ and $\mathbf{8 5 d}$ could easily be isolated in pure form by a simple crystallization in methanol after the optimized reaction time of $60 \mathrm{~min}$. (Scheme 18)

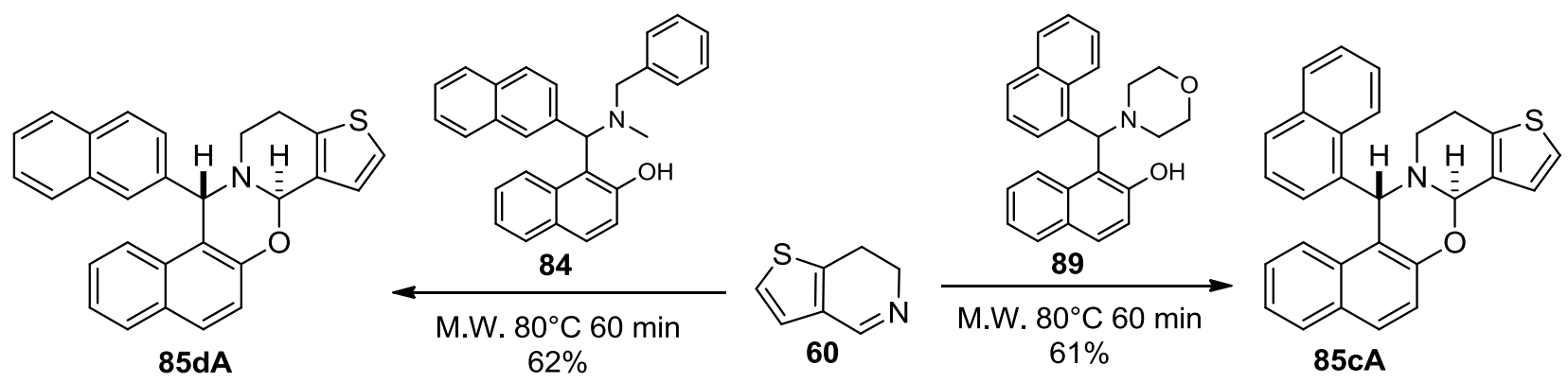

Scheme 18. Synthesis of $\mathbf{8 5 c A}$ and $\mathbf{8 5 d A}$ starting from teriary aminonaphthols

As mentioned above, the synthesis of $\mathbf{8 9}$ was performed starting from 2-naphthol, 1-napthaldehyde and morpholine. Originally, the preparation of the initial tertiary aminonaphthol was planned by using $N$ benzylmethylamine as amine component but instead of giving 90 (II/18), the transformation afforded 91b (II/19b). (Scheme 19)

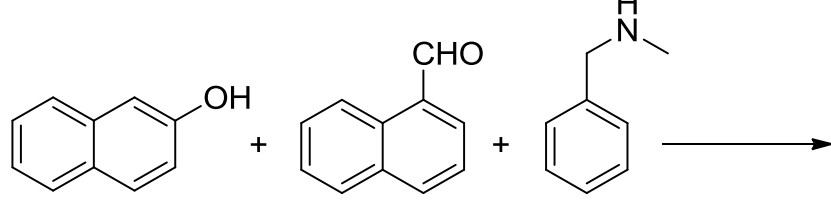<smiles>CC#CO</smiles><smiles>Cc1cccc2ccccc12</smiles>

$91 a$<smiles>Oc1ccc2ccccc2c1C(O)c1cccc2ccccc12</smiles>

$91 b$

Scheme 19. The formation of compound $91 \mathrm{~b}$

This serendipitous reaction prompted us to start a systematic investigation to explore the scope and limitations of the synthesis of $\mathbf{9 1 b}$ analogues. First, the effect of $N$-benzylmethylamine on the formation of 91b was examined. Mechanistically, if an $o-\mathrm{QM}$ structure is formed, the amine component only acts 
as a promoter and does not become incorporated into the product. Therefore, secondary amines with similar basicity were applied first. Piperidine, pyrrolidine and morpholine reacting under neat conditions at $70{ }^{\circ} \mathrm{C}$ gave expected new aminonaphthol derivatives 89, 92 (II/20) and 93 (II/21). (Scheme 20) Dibenzylamine, in turn, showed no reaction. Of related amines such as $N$-methylphenethylamine, 94 (II/22) was isolated as a single product, while $N$-methylaniline proved to be unreactive. A similar failed test to achieve $\mathbf{9 1 b}$ was assumed by using triethylamine, as tertiary amine.<smiles>Oc1ccc2ccccc2c1C(c1cccc2ccccc12)N1CCOCC1</smiles>

89

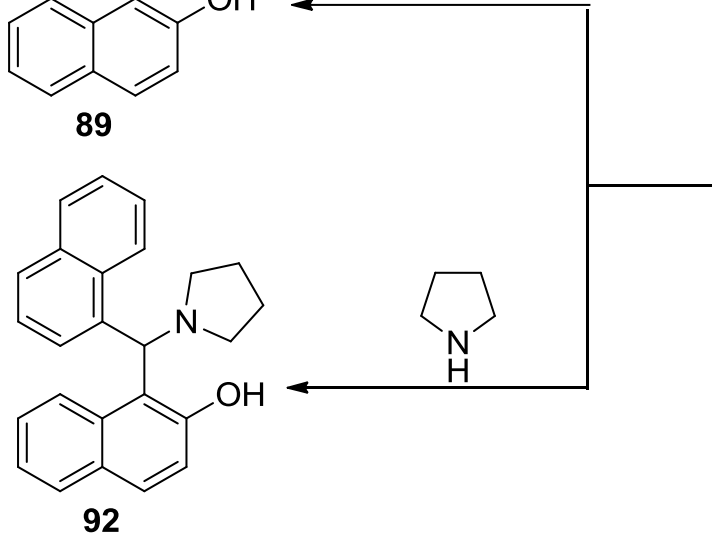

92

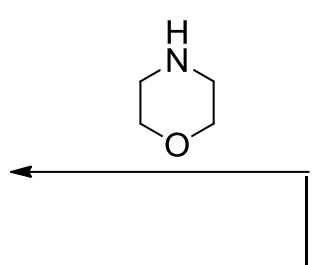<smiles>O=Cc1cccc2ccccc12</smiles>

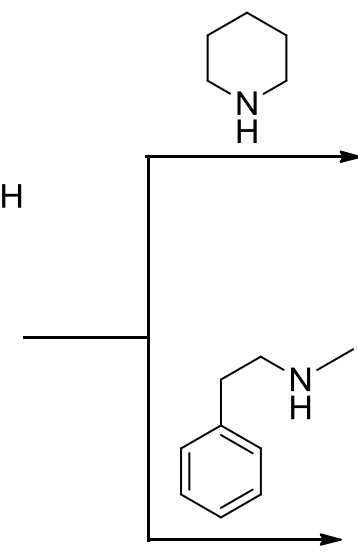<smiles></smiles>

93<smiles>CN(CCc1ccccc1)C(c1cccc2ccccc12)c1c(O)ccc2ccccc12</smiles>

94

Scheme 20. Investigation of the amine scope on $o$-QM formation

In the next step the aldehyde component was changed. First benzaldehyde and 2-naphthaldehyde were tested but both reactions resulted in classical three-component products $\mathbf{8 8}^{110}(I / / 23)$ and $\mathbf{8 1}$. By the application of $p$-anisaldehyde and $p$-nitrobenzaldehyde, the effect of an electron donating and an electron withdrawing group was also examined. In these cases, again, the formation of $o$-QMs was not detected and aminonapthols 95 (II/24) and 96 (II/25) were isolated as single products. (Scheme 21) 
<smiles>CN(Cc1ccccc1)C(c1ccccc1)c1c(O)ccc2ccccc12</smiles>

88<smiles>CN(Cc1ccccc1)C(c1ccc2ccccc2c1)c1c(O)ccc2ccccc12</smiles><smiles>CNCc1ccccc1</smiles><smiles>O=Cc1ccc2ccccc2c1</smiles><smiles>COc1ccc(C(c2c(O)ccc3ccccc23)N(C)Cc2ccccc2)cc1</smiles>

96

Scheme 21. Investigation of the aldehyde scope on $o$-QM formation

\subsubsection{Reactions of ( $4 \mathrm{a} S, 8 \mathrm{a} S)-4 \mathrm{a}, 5,6,7,8,8 \mathrm{a}-\mathrm{h}$ exahydro-2-quinoxalinone and various aminonaphthols}<smiles>NCc1c(O)ccc2ccccc12</smiles>

$78 \mathbf{a}$

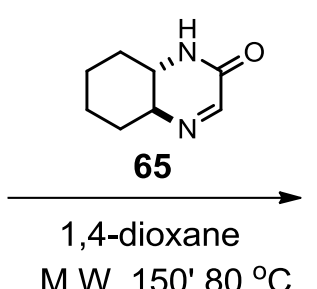

M.W. $150^{\prime} 80^{\circ} \mathrm{C}$

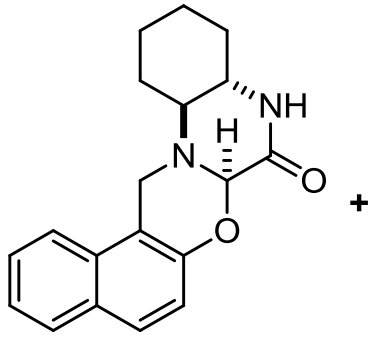

97A<smiles>O=C1N[C@H]2CCCC[C@H]2N2Cc3c(ccc4ccccc34)O[C@H]12</smiles>

97B

Scheme 22. Synthesis of unsubstituted naphthoxazino-quinoxalinones 97

Next, with (4aS,8aS)-4a,5,6,7,8,8a-hexahydro-2-quinoxalinone (65) in hand, the first example known in the literature of the application of an enantiomeric compound in this type of [4+2] cycloaddition reaction was planned to be tested. First, the reaction of 65 with unsubstituted aminonaphthol 78a was probed by heating the mixture under neat conditions at $80{ }^{\circ} \mathrm{C}$. According to TLC, both possible diastereomers $(\mathbf{9 7 A} ; I I I / 3 \mathbf{a}$ and $97 \mathbf{B} ; I I I / 3 \mathbf{b})$ were formed. This obsevation was later confirmed by crude product NMR analysis and a diastereomeric ratio of $1: 0.5$ was found. Since the synthesis required a long reaction ( $14 \mathrm{~h}$ ) affording a conversion of only $28 \%$, the reaction was repeated under microwave irradiation in 1,4-dioxane. In this case, a conversion of $63 \%$ was achieved in $150 \mathrm{~min}$ at the same temperature. (Scheme 22) 
Although the separation of the diastereomers was attempted using both column chromatography in different eluent combinations and recrystallization, the isolated product has remained a mixture of $97 \mathrm{~A}$ and $97 \mathrm{~B}$ in all cases.

Despite of this failure, we managed to achieve complete ${ }^{1} \mathrm{H}$ and ${ }^{13} \mathrm{C}$ assignments of both isomers from their 1:0.5 mixture and 2D-NMR techniques were also applied to prove the formation and clarify the stereochemistry of compounds $97 \mathbf{A}$ and $\mathbf{9 7 B}$. Whereas the H-13a atom is always $\alpha$-arranged, differentiation of the C-7a epimers required to ascertain the relative $\alpha$ or $\beta$ position of the $\mathrm{H}-7 \mathrm{a}$ hydrogen atoms. 2D-NMR studies proved that $\mathrm{H}-7 \mathrm{a}$ in $97 \mathrm{~A}$ has the $\alpha$ position, whereas $\mathrm{H}-7 \mathrm{a}$ in $97 \mathbf{B}$ is located in $\beta$ orientation. Comparing the rather similar ${ }^{13} \mathrm{C}$ chemical shifts of 97A and 97B, significant differences appeared only for the C-13a and C-14 atoms. Namely, these signals exhibit considerable 6-7 ppm diamagnetic shifts in 97B relative to 97A $(61.0 \rightarrow 53.8,47.5 \rightarrow 41.1)$.<smiles>[R]C(N)c1c(O)ccc2ccccc12</smiles>

$\mathrm{R}=\mathrm{Ph}: \mathbf{7 8 b}$ 1-Nph: 78c 2-Nph: 78d

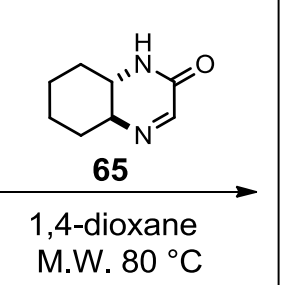
$120-180 \mathrm{~min}$ $-\mathrm{NH}_{3}$

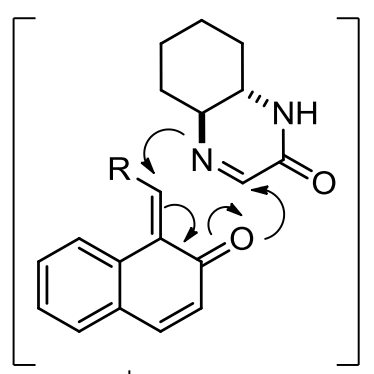

[4+2] cycloaddition

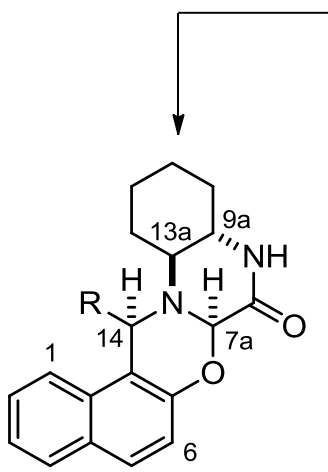

$$
R=\begin{array}{r}
\text { Ph: 98bA, 32\% } \\
\text { 1-Nph: 98cA } \\
\text { 2-Nph: 98dA, 29\% }
\end{array}
$$

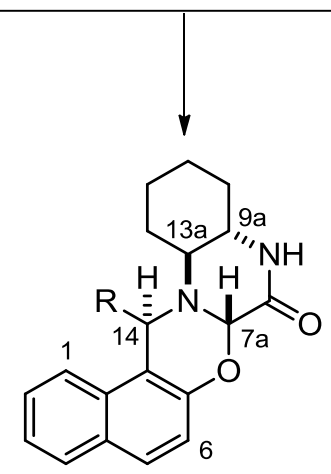

$R=\begin{array}{r}\text { Ph: } \mathbf{9 8 b B}, 19 \% \\ \text { 1-Nph: } 98 \mathrm{cB}, 24 \% \\ \text { 2-Nph: } \mathbf{9 8 d B}, 17 \%\end{array}$

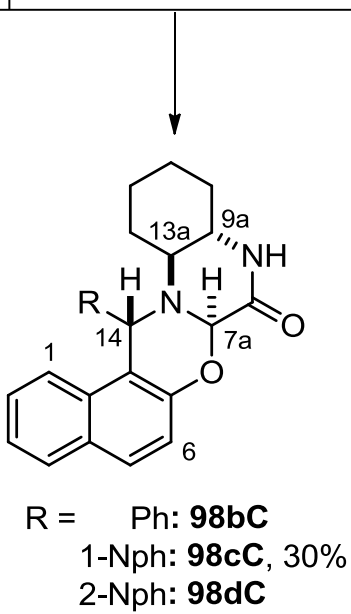

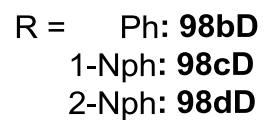

Scheme 23. Reactions of cyclic imine 65 with 1-aminoaryl-2-naphthols $\mathbf{7 8 b - d}$ 
Then we focused on extending the reaction by using 1-aminoalkyl-2-naphthols (78b-d) with varied substitution patterns as initial compounds. In these cases, the formation of four diastereomers is possible. Product formation was monitored by both TLC and crude product NMR analysis. Two diastereomers were formed and isolated in all cases. The stereocentre configurations of the stereoisomers are defined as follows: $7 \mathrm{a} R, 9 \mathrm{a} S, 13 \mathrm{a} S, 14 R$ as $\mathbf{A}, 7 \mathrm{a} R, 9 \mathrm{a} S, 13 \mathrm{a} S, 14 S$ as $\mathbf{B}$, $7 \mathrm{a} S, 9 \mathrm{a} S, 13 \mathrm{a} S, 14 R$ as $\mathbf{C}$ and $7 \mathrm{a} S, 9 \mathrm{a} S, 13 \mathrm{a} S, 14 S$ as $\mathbf{D}$. The configurations of the newly-generated asymmetric centres were assigned by $2 \mathrm{D}$ NMR measurements. Sterically similar aromatic substituents like phenyl and 2-naphthyl were found to favour the formation of $\mathbf{A}$ and $\mathbf{B}$, while $\mathbf{B}$ and $\mathbf{C}$ were formed preferably when the initial aminonaphthol bears a sterically hindered 1naphthyl moiety (isomer ratios are listed in Table 11). Note, that stereoisomer $\mathbf{D}$ has never been detected. (Scheme 23)

Product syntheses using conventional heating afforded quite low conversions (26-34\%) despited relatively long reactions (up to 12-14 h, Table 11). The application of microwave irradiation, however, significantly accelerated the reactions. The mixture of the initial aminoalkyl2-naphthols 78b-d and cyclic imine 65 was heated in 1,4-dioxane at $80{ }^{\circ} \mathrm{C}$. After $120-180 \mathrm{~min}$ reaction time, products $\mathbf{9 8 b}$-d were isolated in higher conversions relative to those found using conventional heating. (Scheme 23, Table 11) Reaction mixtures were purified by column chromatography and diastereomers formed could be separated.

Table 11. Reaction times and conversions by the application of aminoalkyl-naphthols $\mathbf{7 8 b}$-d and 82b-d comparing conventional heating to microwave irradiation

\begin{tabular}{|c|c|c|c|c|c|c|c|c|c|}
\hline \multirow[t]{2}{*}{ Entry } & \multirow[t]{2}{*}{ Products } & \multicolumn{4}{|c|}{$\begin{array}{c}\text { Diastereomers/ } \\
\text { d.r. }\end{array}$} & \multicolumn{2}{|c|}{ Conventional heating } & \multicolumn{2}{|c|}{ MW irradiation } \\
\hline & & $\mathbf{A}$ & B & $\mathbf{C}$ & $\mathbf{D}$ & Time & Conversion & Time & Conversion \\
\hline 1 & 98b & 1 & 0.5 & - & - & $14 \mathrm{~h}$ & $31 \%$ & $180 \mathrm{~min}$ & $59 \%$ \\
\hline 2 & $98 c$ & - & 1 & 1.3 & - & $12 \mathrm{~h}$ & $27 \%$ & $120 \mathrm{~min}$ & $54 \%$ \\
\hline 3 & 98d & 1 & 0.6 & - & - & $12 \mathrm{~h}$ & $26 \%$ & $120 \mathrm{~min}$ & $51 \%$ \\
\hline 4 & 99b & 1 & - & - & - & $7 \mathrm{~h}$ & $34 \%$ & $60 \mathrm{~min}$ & $62 \%$ \\
\hline 5 & $99 c$ & 1 & - & - & - & $9 \mathrm{~h}$ & $28 \%$ & $90 \mathrm{~min}$ & $64 \%$ \\
\hline 6 & 99d & 1 & - & - & - & $9 \mathrm{~h}$ & $31 \%$ & $90 \mathrm{~min}$ & $68 \%$ \\
\hline
\end{tabular}




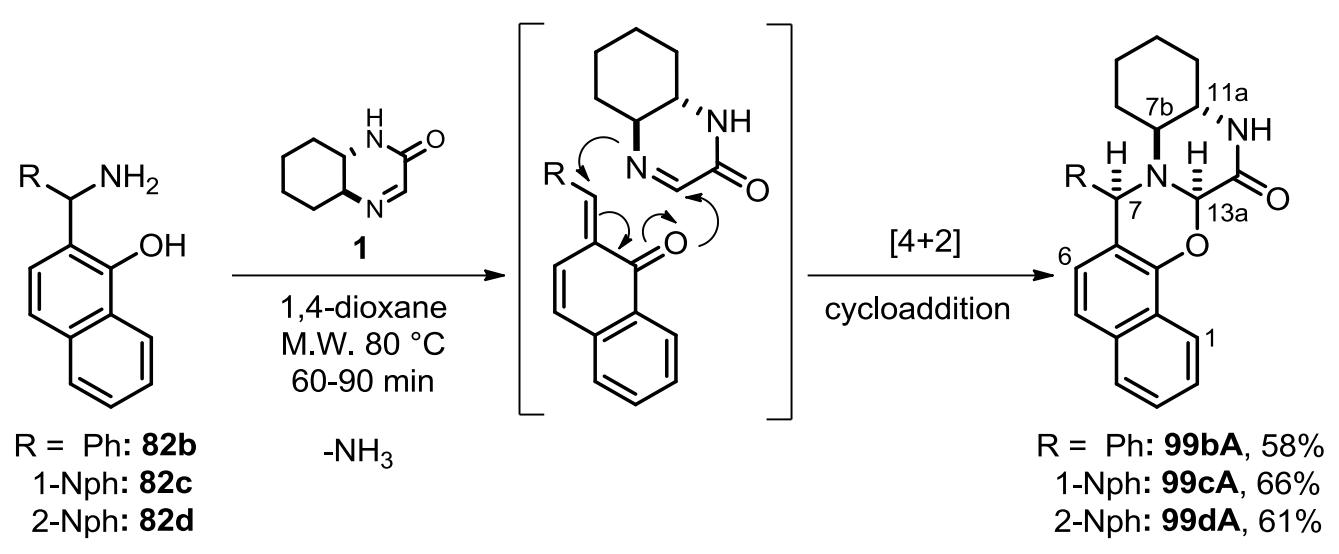

Scheme 24. Reactions between cyclic imine 65 and 2-aminoaryl-1-naphthols 82b-d

To extend the line of novel enantiomeric naphthoxazino-quinoxalinones, 2-aminoaryl-1naphthols (82b-d) were then applied as starting materials. On the basis of our previous studies, microwave irradiation was used to achieve increased yields in shorter reactions. After 60-90 minutes in 1,4-dioxane at $80^{\circ} \mathrm{C}$, TLC showed the formation of a single new compound in each case. Further crude product NMR studies confirmed the diastereoselectivity of the reactions. Purification by column chromatography afforded the desired pentacycles (99b-d, Scheme 24) in good yields. Further 2D NMR measurements of the isolated compounds (99b-d) indicated that the configurations of the newly-generated stereocentres are identical to those in $\mathbf{A}$.

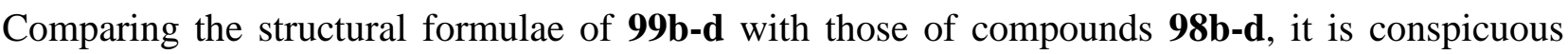
that now there is spatial proximity and steric repulsion between the $\mathrm{R}$ substituent and the condensed naphthalene ring. Consequently, no restricted rotation of the phenyl, 1- or 2-napthyl groups were observed.

\subsubsection{Conformational analysis of the new napth $[1,3]$ oxazino[2,3-a]heterocycles}

In the case of polyheterocycles fused with benzazepine and thienopyridine, the trans structure of compound type A was unambiguously evidenced by the NOESY cross peaks revealing interactions between the oxazine proton of the $\mathrm{NCHO}$ group and the proximal protons of the attached aryl substituent. Accordingly, the characteristic NOEs detected between the two oxazine protons of the isolated pentacycles $(\mathbf{8 3 b B}, 83 \mathrm{~dB}, 86 \mathrm{bB}$ and $86 \mathrm{~dB})$ refer to their relative cis position on the fused heterocyclic skeleton.

In order to obtain information about the conformation and possible ring inversions of the pentacycles, a comparative DFT analysis of representative fused benzazepine $\mathbf{8 3 \mathbf { b A }}$ was carried 
out by B3LYP functional using 6-31G(d) as basis set. ${ }^{103-105}$ It was clearly shown that at the global minimum, a chair-shaped azepine ring is present. It must also be pointed out that at room temperature the low barriers allow fast interconversions between the conformers taking place by ring flips and inversion of the bridgehead nitrogen atom. (Figure 4)

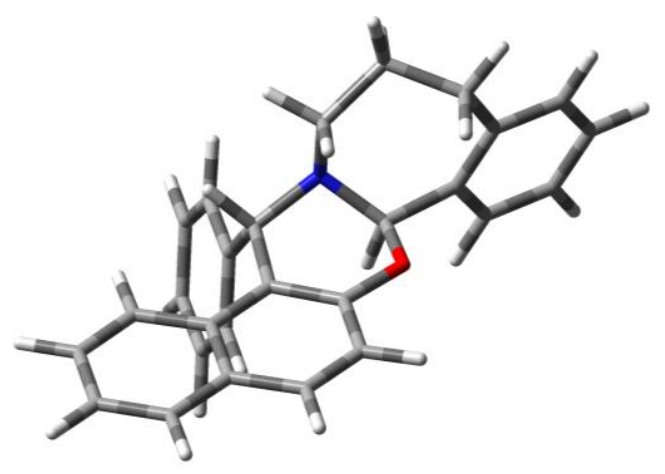

83bA_I

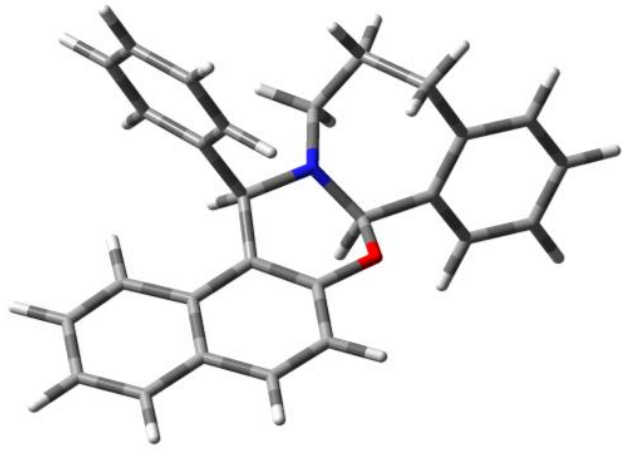

83bB_III

Figure 4. Minimum conformers for the compounds 83bA and $83 \mathrm{bB}$

To get a better insight into the stereochemistry of the novel naphthoxazine-fused polyheterocycles, our final goal was to acquire more information about the geometries of the quinoxalinone-fused derivatives. Considering the preferred conformation of $\mathbf{9 7 A}$, it is obvious that the quinoxalinone ring exists in a half-chair conformation, where the 7a, 8, 9, 9a atoms are coplanar and $\mathrm{N}-13 \mathrm{~b}$ is above and $\mathrm{C}-13 \mathrm{a}$ under the plane. DFT calculations also showed that the oxazino ring in compounds 97A and 97B appear in an envelope conformation with an out-of-plane C-7a atom. (Figure 5)

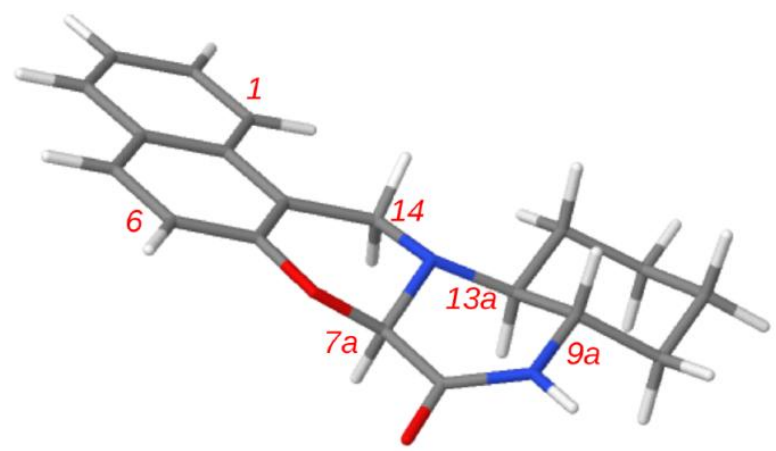

97A

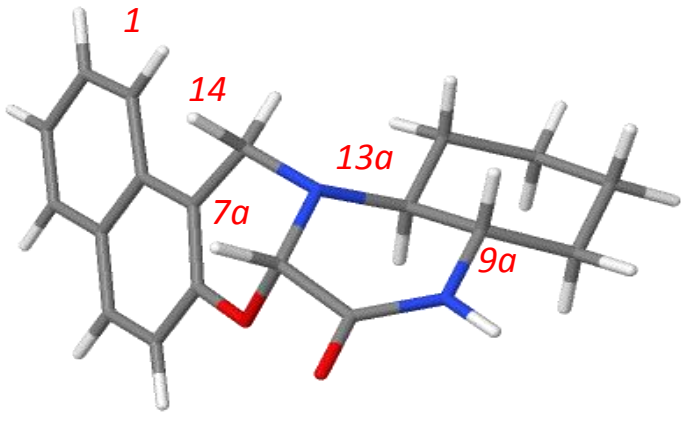

97B

Figure 5. Minimum conformers for compounds 97A and 97B 
The configurations of the newly-generated stereogenic centres in compounds $\mathbf{9 8 \mathbf { b }} \mathbf{- d}$ were elucidated by comprehensive NMR measurements. The quinoxalinone ring adopts a half-chair conformation, where the $7 \mathrm{a}, 8,9,9 \mathrm{a}$ atoms are coplanar and $\mathrm{N}-13 \mathrm{~b}$ is above and $\mathrm{C}-13 \mathrm{a}$ under the plane. Analogous to 97a, H-7a always takes the $\alpha$ position with the exception of compound 98dB,

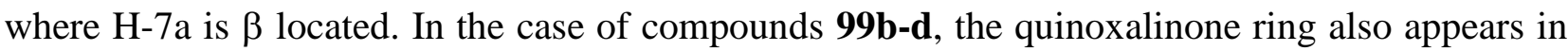
half-chair conformation, where the $11 \mathrm{a}, 12,13,13 \mathrm{a}$ atoms are coplanar whereas $\mathrm{N}-7 \mathrm{a}$ is above and $7 \mathrm{~b}$ under the plane. 


\section{SUMMARY}

1. C1 couplings of 4,5-dihydro-3H-benz[c]azepine and 6,7-dihydrothieno[3,2-c]pyridine were achieved by reacting cyclic imines with 1- or 2-naphthol under neat conditions resulting in hydroxynaphthyl-benzazepines 60, 61 and hydroxynaphthyl-thienopyridines $65,66 . N$-Containing naphthol analogues such as 5-hydroxyisoquinoline and 6-hydroxyquinoline were also applied. Achieving the transformations under microwave irradiation at $80{ }^{\circ} \mathrm{C}$, hydroxyisoquinolyl and hydroxyquinolyl derivatives 62, 63, 67 and 68 were isolated as novel bifunctional compounds. Comparing the syntheses to those of naphthols, the desired products were isolated in lower yields in longer reactions.

2. Syntheses were then extended by the application of $(4 \mathrm{a} S, 8 \mathrm{a} S)-4 \mathrm{a}, 5,6,7,8,8 \mathrm{a}-$ hexahydro-2quinoxalinone as cyclic imine component in $\mathrm{C} 1$ coupling reactions. In these cases, conventional heating was preferred. The preparation of hydroxynaphthyl-quinoxalinones by the application of 2naphthol found to be diastereoselective, while in the case of 1-naphthol, the formation of (3'S,3"R,4a'S,4a"'S,8a'S,8a"S)-3',3"-(4-hydroxynaphthalene-1,3-diyl)bis(octahydroquinoxalin-2'-one) 71c was also detected in around 10\% amongst the two possible diastereomers 71a and 71b.

3. Isolated bifunctional compounds 60-68, 70a, 71a-c underwent cyclizating reactions using a $35 \%$ aqueous solution of formaldehyde as cyclizing agent. Achieving the reactions at room temperature in dichloromethane, the desired naphthoxazine-, oxazino-isoquinoline- and oxazino-quinoline-fused polyheterocycles $(\mathbf{7 2 - 7 9}, \mathbf{8 0 a}-\mathbf{b}, \mathbf{8 1})$ were formed in short reactions with excellent yields, except for 71c as starting material. In this case, the addition of formaline led to decomposition and no product was isolated.

4. A synthetic route to annelational analogue naphth[1,3]oxazino[2,3-a]benzazepines and thienopyridines was developed. Starting from 4,5-dihydro-3H-benz[c]azepine or 6,7dihydrothieno[3,2-c]pyridine and variously substituted primary aminonaphthols (78a-d, 82b-d), the formation of desired polyheterocycles 79a-d, 83b-d, 85a-d, 86b-d occurred together with unexpected side products $(\mathbf{8 0 b}-\mathbf{d}, \mathbf{8 4} \mathbf{b}-\mathbf{d})$. The formation of the possible diastereomers was also investigated by crude product NMR analysis. The corresponding data indicated the presence of

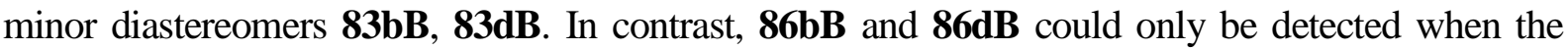
reaction was performed with aminonaphthols $\mathbf{8 2 b}$ or $\mathbf{8 2 d}$. The diastereoselectivity of the reaction 
was found to depends on the steric effect of the aromatic ring at position 14 or 16 and on the position of annulation of the naphthalene ring. In most cases, the separation of desired naphthoxazines from side products could succesfully be achieved; however, 79d, 83c and 83d could not be isolated in pure form. Consequently, a new synthetic strategy was developed.

5. A systematic study was carried out to compare the reactivity and applicability of primary, secondary and tertiary aminonaphthols in the [4+2] cycloaddition reaction. Based on this study, tertiary aminonaphthols afforded the best results. Therefore, the synthesis of 16-naphth-2-yl-naphth[1,2$e][1,3]$ oxazino[2,3-a]benz[c]azepine $\quad$ 79d, 14-naphth-1-yl-naphth[1,2-e][1,3]oxazino[2,3-a]-6,7dihydrothieno[3,2-c]pyridine $\mathbf{8 3 c}$ and 14-naphth-2-yl-naphth[1,2-e][1,3]oxazino[2,3-a]-6,7dihydrothieno[3,2-c]pyridine 83d was achieved starting from tertiary aminonaphthols $\mathbf{8 1}$ and $\mathbf{8 9}$. During the preparation of the initial bifunctional compounds, an unexpected transformation led to the formation of $\mathbf{9 1}$. The scope and limitations of its formation were investigated from the point of view of both amine and aldehyde scopes but no product with a structure similar to that of $\mathbf{9 1}$ could be isolated.

6. A simple method was developed for the synthesis of naphth[1,3] oxazino[3,2-a]quinoxalinones. Starting from enantiomeric hexahydroquinoxalinone 65 and 1-aminoalkyl-2-naphthols 78a-d or 2aminoalkyl-1-naphthols 82b-d, successful transformations were accomplished at $80{ }^{\circ} \mathrm{C}$ under microwave irradiation. The formation of the possible diastereomers was confirmed by crude product NMR spectra. Starting from 82b-d, the syntheses proved to be diastereoselective and 99bA-99dA were isolated as single products. By the application of aminonaphthols 78a-d, two of the four possible diastereomers $(98 \mathrm{bA}$ and $98 \mathrm{bB}, 98 \mathrm{cB}$ and $98 \mathrm{cC}, 98 \mathrm{dA}$ and $98 \mathrm{~dB})$ were formed. 


\section{ACKNOWLEDGEMENTS}

This work was carried out in the Institute of Pharmaceutical Chemistry, University of Szeged, during the years 2013-2017.

I would like to express my deepest thanks to my supervisor, Professor Ferenc Fülöp for his guidance of my work, his inspiring ideas, his useful advice and his constructive criticism.

My warmest thanks are due to my co-supervisor Dr. István Szatmári, for his continuous support and interest in my activities. His advice and help have been invaluable during all stages of my work.

I would like to thank all members of Research Laboratory 3 (nowadays it is Research Laboratory 4) at the Institute of Pharmaceutical Chemistry for their help and friendship. I feel very fortunate to be able to work in such a collaborative environment.

Finally, I would like to give my special thanks to my family for their love and support during my Ph.D. studies. 


\section{REFERENCES}

1. Bur, S. K.; Martin, S. F. Tetrahedron 2001, 57, 3221.

2. Speckamp, W. N.; Moolenaar, M. J. Tetrahedron 2000, 56, 3817.

3. Arend, M.; Westermann, B.; Risch, N. Angew. Chem. Int. Ed. Engl. 1998, 37, 1045.

4. Liras, S.; Davoren, J. E.; Bordner, J. Org. Lett. 2001, 3, 703.

5. Ito, M.; Clark, C. W.; Mortimore, M.; Goh, J. B.; Martin, S. F. J. Am. Chem. Soc. 2001, $123,8003$.

6. Szatmári, I.; Fülöp, F. Curr. Org. Synth. 2004, 1, 155.

7. Betti, M. Gazz. Chim. Ital. 1900, 30 II, 310.

8. Betti, M. Gazz. Chim. Ital. 1901, 31 II, 377.

9. Betti, M. Gazz. Chim. Ital. 1901, 31 II, 170.

10. Betti, M. Gazz. Chim. Ital. 1901, 31 II, 191.

11. Betti, M. Org. Synth. Coll. Vol. 1941, 1, 381.

12. Szatmári, I.; Fülöp, F. Tetrahedron, 2013, 69, 1255.

13. Szatmári, I.; Hetényi, A.; Lázár, L.; Fülöp, F. J. Heterocycl. Chem. 2004, 41, 367.

14. Heydenreich, M.; Koch, A.; Klod, S.; Szatmári, I.; Fülöp, F.; Kleinpeter, E. Tetrahedron 2006, 62, 11081.

15. Csütörtöki, R.; Szatmári, I.; Koch, A.; Heydenreich, M.; Kleinpeter, E.; Fülöp, F. Tetrahedron 2011, 67, 8564.

16. Csütörtöki, R.; Szatmári, I.; Heydenreich, M.; Koch, A.; Starke, I.; Fülöp, F.; Kleinpeter, E. Tetrahedron 2012, 68, 4600 .

17. Heydenreich, M.; Koch, A.; Szatmári, I.; Fülöp, F.; Kleinpeter, E. Tetrahedron 2008, 64, 7378.

18. Van De Water, R. W.; Pettus, T. R. R. Tetrahedron 2002, 58, 5367.

19. Willis, N. J.; Bray, C. D. Chem. Eur, J. 2012, 18, 9160.

20. Bai, W-J.; David, J. G.; Feng, Z-G.; Weaver, M. G.; Wu, K-L.; Pettus, T. R. R. Acc. Chem. Res. 2014, 47, 3655.

21. Toteva, M. M.; Richard, J. P. Adv. Phys. Org. Chem. 2011, 45, 39.

22. Osipov, D. V.; Osyanin, V. A.; Klimochkin, Y. N. Russ. Chem. Rev. 2017, 86, 625.

23. Szatmári, I.; Fülöp, F. Tetrahedron Lett. 2011, 52, 4440.

24. Csütörtöki, R.; Szatmári, I.; Fülöp, F. Curr. Org. Synth. 2013, 10, 564.

25. Nasr-Esfahani, M.; Montazerozohori, M.; Taei, M. C. R. Chim. 2016, 19, 986.

26. Zali, A.; Shokrolahi, A. Chin. Chem. Lett. 2012, 23, 269. 
27. Borhade, A. V.; Uphade, B. K.; Tope, D. R. Res. Chem. Intermed. 2014, 14, 211.

28. Safari, J.; Zarnnegar, Z. J. Mol. Catal. A: Chem. 2013, 379, 269.

29. Zolfigol, M. A.; Baghery, S.; Moosavi-Zare, A. R.; Vahdat, S. M.; Alinezhad, H.; Norouzi, M. RSC Adv. 2015, 5, 45027.

30. Hajipour, A. R.; Ghayeb, Y.; Sheikhan, N.; Ruoho, A. E. Tetrahedron Lett. 2009, 50, 5649.

31. Mulla, A. R. S.; Salama, T. A.; Pathan, M. Y.; Inamdar, S. M.; Chavan, S. S. Tetrahedron Lett. 2013, 54, 672.

32. Kotadia, D. A.; Soni, S. S. J. Mol. Catal. A: Chem. 2012, 353-354, 44.

33. Muskawar, P. N.; Kumar, S. S.; Bhagat, P. R. J. Mol. Catal. A: Chem. 2013, 380, 112.

34. Safari, J.; Zarnegar, Z. Ultrason. Sonochem. 2014, 21, 1132.

35. Khodaei, M. M.; Khosropour, A. R.; Morghanian, H. Synlett 2006, 6, 916.

36. Kantevari, S.; Vuppalapati, V. N.; Nagarapu, L. Catal. Commun. 2007, 8, 1857.

37. Patil, S. B.; Singh, P. R.; Surpur, M. P.; Samant, S. D. Synth. Commun. 2007, 37, 1659.

38. Das, B.; Laxminarayana, K.; Ravikanth, B.; Rao, B. R. J. Mol. Catal. A: Chem. 2007, 261,180 .

39. Nagarapu, L.; Baseeruddin, M.; Apuri, S.; Kantevari S. Catal. Commun. 2007, 8, 1729.

40. Mahdavinia, G. H.; Bigdeli, M. A.; Heravi, M. M. Chin. Chem. Lett. 2008, 19, 1171.

41. Shaterian, H. R.; Yarahmadi, H.; Ghashang, M. Tetrahedron 2008, 64, 1263.

42. Das, B.; Kumar, D. N.; Laxminarayana, K.; Ravikanth, B. Helv. Chim. Acta 2007, 90, 1330.

43. Srihari, G.; Nagaraju, M.; Murthy, M. M. Helv. Chim. Acta 2007, 90, 1497.

44. Anary, A. M.; Hassanabadi, A.; Kamali, G. M.; Saidipoor, A.; Anaraki, A. H. J. Chem. Res. 2007, 11, 644.

45. Shaterian, H. R.; Yarahmadi, H. Arkivoc 2008, 105.

46. Shaterian, H. R.; Yarahmadi, H.; Ghashang, M. Bioorg. Med. Chem. Lett. 2008, 18, 788.

47. Su, W. K.; Tang, W. Y.; Li, J. J. J. Chem. Res. 2008, 3, 123.

48. Khabazzadeh, H.; Saidi, K.; Seyedi, N. J. Chem. Sci. 2009, 121, 429.

49. Mahdavinia, G. H.; Bigdeli, M. A. Chin. Chem. Lett. 2009, 20, 383.

50. Patil, S. B.; Singh, P. R.; Surpur, M. P.; Samant, S. D. Ultrason. Sonochem 2007, 14, 515.

51. Nagawade, R. R.; Shinde, D. B. Mendeleev Commun. 2007, 17, 299.

52. Ganesh, C. N.; Subhasis, S.; Ram, K.; Singh, M. S. Tetrahedron Lett. 2009, 50, 7220.

53. Shaterian, H. R.; Azizi, K.; Fahimi, N. Chem. Sci. Trans. 2012, 1, 73. 
54. Vaghei, R. G.; Malaekehpour, S. M. Cent. Eur. J. Chem. 2010, 8, 1086.

55. Wang, C.; Wan, Y.; Wang, H. Y.; Zhao, L. I.; Zhang, X. X.; Wu, H. J. Heterocyclic Chem. 2013, 50, 496.

56. Hazeri, N.; Maghsoodlou, M. T.; Habibi-Khorassani, S. M.; Aboonajmi, J.; Safarzaei, M. Chem. Sci. Trans. 2013, 2, S330.

57. Singh, R. K.; Duvedi, R. Arab. J. Chem. 2018, 11, 91.

58. Li, T.; Zhai, X.; Singh, R. K.; Xu, X. Asian J. Chem. 2014, 26, 5207.

59. Davoodnia, A.; Mahjoobin, R.; Tavakoli, H. N. Chin. J. Catal. 2014, 35, 490.

60. Shaikh, K. A.; Chaudhar, U. N.; Vijaykumar, B. N. J. Appl. Chem. 2014, 7, 90.

61. Singh, R. K.; Singh, B.; Duvedi, R.; Kumar, S. Res. Chem. Intermed. 2015, 41, 4083.

62. Wang, M.; Liang, Y.; Zhang, T. T.; Gao, J. J. Chin. Chem. Lett. 2012, 23, 65.

63. Niralwad, K. S.; Shingate, B. B.; Shingare, M. S. Chin. Chem. Lett. 2011, 22, 551.

64. Hashemi, H.; Sardarian, A. R. J. Iran. Chem. Soc. 2013, 10, 745.

65. Rani, G. S.; Reddy, V. K. S.; Prasad, R. B. N.; Devi, B. L. A. P. Int. J. Adv. Res. Chem. Sci. 2015, 2, 22.

66. Hajjami, M.; Ghorbani, F.; Bakhti, F. Appl. Catal., A: Gen. 2014, 470, 303.

67. Moghanian, H.; Ebrahimi, S. J. Saudi Chem. Soc. 2014, 18, 165.

68. Forouzani, M.; Ghasemnejad-Bosra, H. Arab. J. Chem. 2016, 9, S752.

69. El Kaïm, L.; Grimaud, L., Oble, J. Org. Biomol. Chem. 2006, 4, 3410.

70. Mudududdla, R.; Jain, S. K.; Bharate, J. B.; Gupta, A. P.; Singh, B.; Vishwakarma, R. A.; Bharate, S. B. J. Org. Chem. 2012, 77, 8821.

71. Sharma, R.; Abbat, S.; Mudududdla, R.; Vishwakarma, R. A.; Bharatam, P. V.; Bharate, S. B. Tetrahedron Lett. 2015, 56, 4057.

72. Cherkadu, V.; Kalavagunta, P. K.; Ravirala, N.; Shivananju, N. S.; Priya, B. S. Synlett 2016, 27, 2795.

73. Nakatani, K.; Higashida, N.; Saito, I. Tetrahedron Lett. 1997, 38, 5005.

74. Osyanin, V. A.; Osipov, D. V.; Klimochkin, Y. N. Tetrahedron 2012, 68, 5612.

75. Pettigrew, J. D.; Freeman, R. P.; Wilson, P. D. Can. J. Chem. 2004, 82, 1640.

76. Osipov, D. V.; Osyanin, V. A.; Klimochkin, Y. N. Synlett 2012, 23, 917.

77. Osyanin, V. A.; Ivleva, E. A.; Klimochkin, Y. N. Synth. Commun. 2012, 42, 1832.

78. Osyanin, V. A.; Osipov, D. V.; Klimochkin, Y. N. J. Org. Chem. 2013, 78, 5505.

79. Willis, N. J.; Bray, C. D. RSC Adv. 2015, 5, 80212.

80. Huang, P-J. J.; Cameron, S.; Jha, A. Tetrahedron Lett. 2009, 50, 51. 
81. Schenck, L. W.; Kuna, K.; Frank, W.; Albert, A.; Asche, C.; Kucklaender, U. Bioorg. Med. Chem. 2006, 14, 3599.

82. Bilgic, S.; Bilgic, O.; Büyükkidan, B.; Gündüz, M. J. Chem. Res. 2007, 31, 76.

83. Osyanin, V. A.; Ivleva, E. A.; Osipov, D. V.; Klimochkin, Y. N. Chem. Heterocycl. Compd. 2011, 47, 845.

84. Osyanin, V. A.; Ivleva, E. A.; Klimochkin, Y. N. Chem. Heterocycl. Compd. 2012, 48, 795.

85. Frasinyuk, M. S.; Mrug, G. P.; Bondarenko, S. P.; Khilya, V. P.; Sviripa, V. M.; Syrotchuk, O. A.; Zhang, W.; Cai, X.; Fiandalo, M. V.; Mohler, J. L.; Liu, C.; Watt, D. S. ChemMedChem 2016, 11, 600 .

86. Liao, H-H.; Chatupheeraphat, A.; Hsiao, C-C.; Atodiresei, I.; Rueping, M. Angew. Chem. Int. Ed. 2015, 54, 15540.

87. Deb, M. L.; Dev Pegu, C.; Deka, B.; Dutta, P.; Kotmale, A. S.; Baruah, P. K. Eur. J. Org. Chem. 2016, 3441.

88. Deb, M. L.; Das, C.; Deka, B.; Saikia, P. J.; Baruah, P. K. Synlett 2016, 27, 2788.

89. Modica, E.; Zanaletti, R.; Freccero, M.; Mella, M. J. Org. Chem. 2001, 66, 41.

90. Kumar, D.; Rokita, S. E. Tetrahedron Lett. 2004, 45, 2887.

91. Ishida, H.; Sanders, D. P. Polymer 2001, 42, 3115.

92. Kearney, A. S.; Patel, K.; Palepu, N. R. Int. J. Pharm. 1996, 127, 229.

93. Dimmock, J. R.; Erciyas, E.; Kumar, P.; Hetherington, M.; Quail, J. W.; Pugazhenthi, U.; Arpin, S. A.; Hayes, S. J.; Allen, T. M.; Halleran, S.; De Clercq, E.; Balzarini, J.; Stables, J. P. Eur. J. Med. Chem. 1997, 32, 583.

94. Verga, D.; Nadai, M.; Doria, F.; Percivalle, C.; Di Antonio, M.; Palumbo, M; Richter, S. N.; Freccero, M. J. Am. Chem. Soc. 2010, 132, 14625.

95. Neves, A. P.; Pereira, M. X. G.; Peterson, E. J.; Kipping, R.; Vargas, M. D.; Silva-Jr, F. P.; Carneiro, J. W. M.; Farrell, N. P. J. Inorg. Biochem. 2013, 119, 54.

96. Da Silva, G. B.; Neves, A. P.; Vargas, M. D.; Marinho-Filho, J. D. B.; Costa-Lotufo, L. V. Bioorg. Med. Chem. Lett. 2016, 26, 3537.

97. Zhang, L.; Ren, L.; Minghui, B.; Weng, L.; Huang, J.; Wu, L.; Deng, M.; Zhou, X. Bioorg. Med. Chem. 2007, 15, 6920.

98. Weinert, E. E.; Dondi, R.; Colloredo-Melz, S.; Frankenfield, K. N.; Mitchell, C. H.; Freccero, M.; Rokita, S. E. J. Am. Chem. Soc. 2006, 128, 11940.

99. Meyers, A. I.; Hutchings, R. H. Tetrahedron 1993, 49, 1807.

100. Jakubec, P.; Helliwell, M.; Dixon, D. J. Org. Lett. 2008, 10, 4267. 
101. Herz, W. I.; Tsai, L. J. Am. Chem. Soc. 1955, 77, 3529.

102. Minakawa, M.; Guo, H.-M.; Tanaka, F. J. Org. Chem. 2008, 73, 8669.

103. Frisch, M. J.; Trucks, G. W.; Schlegel, H. B.; Scuseria, G. E.; Robb, M. A.;

Cheeseman, J. R.; Scalmani, G.; Barone, V.; Mennucci, B.; Petersson, G. A.; Nakatsuji,

H.; Caricato, M.; Li, X.; Hratchian, H. P.; Izmaylov, A. F.; Bloino, J.; $\quad$ Zheng, G.;

Sonnenberg, J. L.; Hada, M.; Ehara, M.; Toyota, K.; Fukuda, R.; Hasegawa, J.; Ishida,

M.; Nakajima, T.; Honda, Y.; Kitao, O.; Nakai, H.; Vreven, T.; $\quad$ Montgomery, T. A.;

Peralta, Jr. J. E.; Ogliaro, F.; Bearpark, M.; Heyd, J. J.; Brothers, $\quad$ E.; Kudin, K. N.;

Staroverov, V. N.; Kobayashi, R.; Normand, J.; Raghavachari, K.; Rendell, A.; Burant,

J. C.; Iyengar, S. S.; Tomasi, J.; Cossi, M.; Rega, N.; Millam, J. $\quad$ M.; Klene, M.; Knox,

J. E.; Cross, J. B.; Bakken, V.; Adamo, C.; Jaramillo, J.; Gomperts, R.; Stratmann, R. E.;

Yazyev, O.; Austin, A. J.; Cammi, R.; Pomelli, C.; Ochterski, J. W.; Martin, R. L.;

Morokuma, K.; Zakrzewski, V. G.; Voth, G. A.; Salvador, P.; Dannenberg, J. J.; Dapprich,

S.; Daniels, A. D.; Farkas, O.; Foresman, J. B.; Ortiz, J. V.; Cioslowski, J.; Fox, D. J.

Gaussian 09, Revision A.02, Gaussian, Inc., Wallingford CT, 2009.

104. Hehre, W. J.; Radom, L.; von Ragué Schleyer, P.; Pople, J. Ab Initio Molecular Orbital

Theory; Wiley: New York, NY, 1986.

105. Becke, A. D. J. Chem. Phys. 1993, 98, 1372.

106. Szatmári, I.; Martinek, T. A.; Lázár, L.; Fülöp, F. Tetrahedron 2003, 59, 2877.

107. Tóth, D.; Szatmári, I.; Fülöp, F. Eur. J. Org. Chem. 2006, 4664.

108. Tóth, D.; Szatmári, I.; Heydenreich, M.; Koch, A.; Kleinpeter, E.; Fülöp, F. J. Mol. Struct. 2009, 929, 58.

109. Cimarelli, C.; Mazzanti, A.; Palmieri, G.; Volpini, E. J. Org. Chem. 2001, 66, 4759.

110. Deb, M. L.; Dey, S. S.; Bento, I.; Barros, M. T.; Maycock, C. D. Angew. Chem. Int. Ed. 2013, 52, 9791. 
ANNEX 